Prepared in cooperation with the Strategic Environmental Research and Development Program

\title{
Storage Capacity of the Fena Valley Reservoir, Guam, Mariana Islands, 2014
}

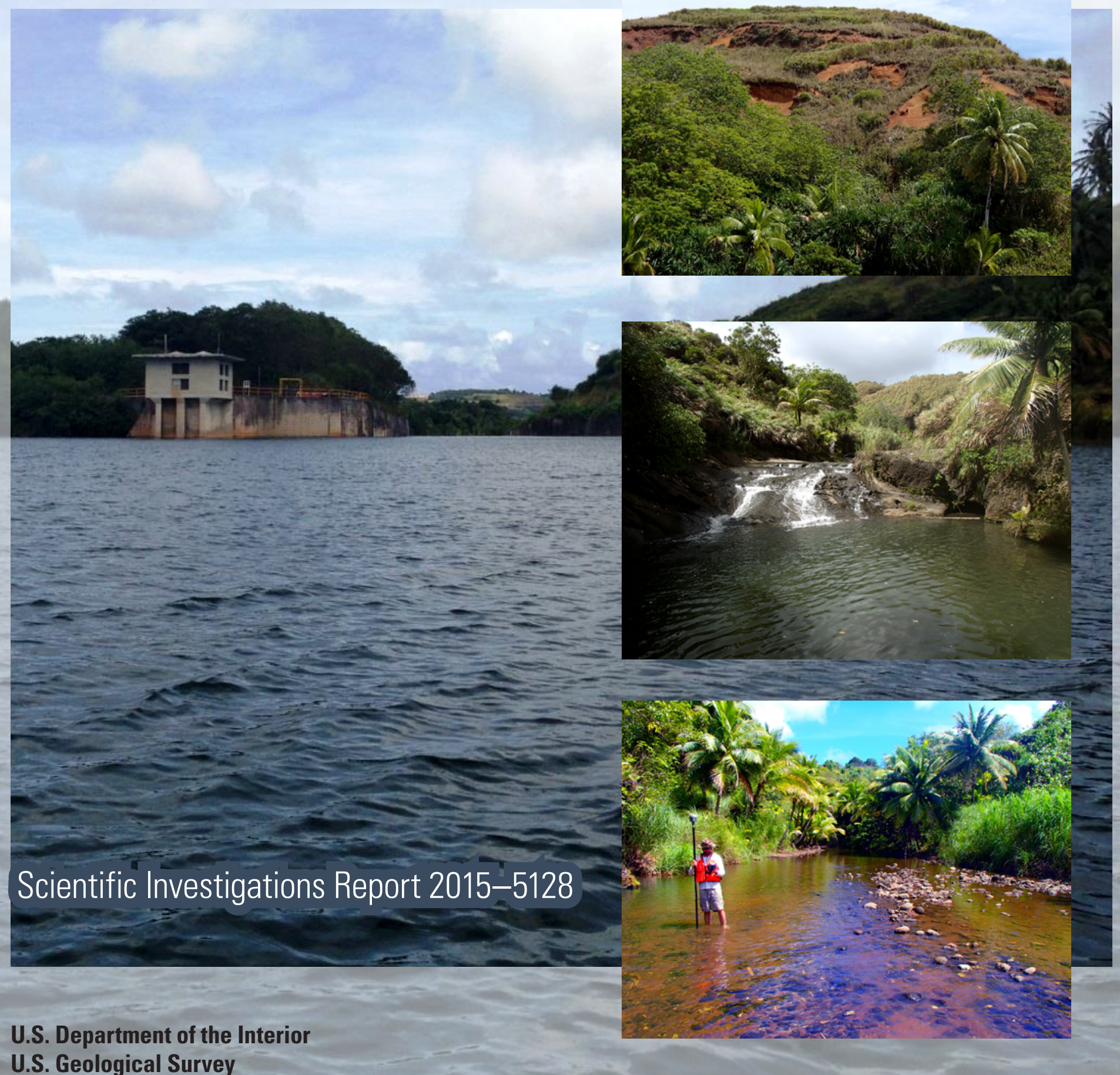




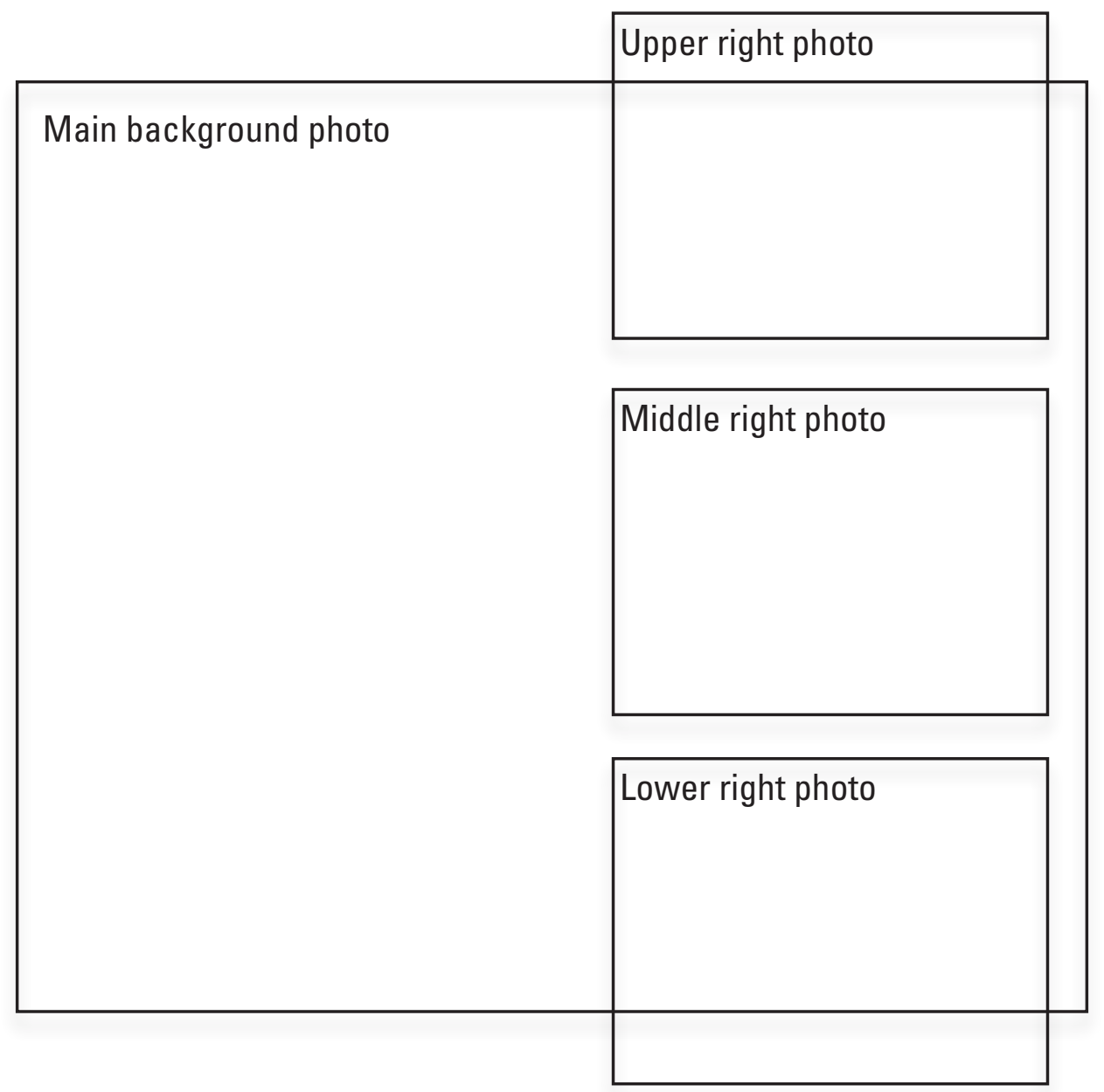

Cover. Main Cover Photo: Fena Valley Reservoir with view of intake-screen house and spillway. (Photograph by S.A. Wright, U.S. Geological Survey, February 24, 2014)

Upper right photo: Erosion on steep slopes in the Fena Valley Reservoir Watershed. (Photograph by M.D. Marineau, U.S. Geological Survey, February 22, 2014)

Middle right photo: Imong River upstream from the Fena Valley Reservoir. (Photograph by M.D. Marineau, U.S. Geological Survey , February 23, 2014)

Lower right photo: U.S. Geological Survey hydrologist Mathieu Marineau surveying a section of the Imong River just upstream of the Fena Valley Reservoir. (Photograph by S.A. Wright, U.S. Geological Survey, February 23, 2014) 


\section{Storage Capacity of the Fena Valley Reservoir, Guam, Mariana Islands, 2014}

By Mathieu D. Marineau and Scott A. Wright

Prepared in cooperation with the Strategic Environmental Research and

Development Program

Scientific Investigations Report 2015-5128 


\title{
U.S. Department of the Interior SALLY JEWELL, Secretary
}

\section{U.S. Geological Survey \\ Suzette M. Kimball, Acting Director}

\author{
U.S. Geological Survey, Reston, Virginia: 2015
}

For more information on the USGS - the Federal source for science about the Earth, its natural and living resources, natural hazards, and the environment—visit http://www.usgs.gov or call 1-888-ASK-USGS.

For an overview of USGS information products, including maps, imagery, and publications, visit http://www.usgs.gov/pubprod/.

Any use of trade, firm, or product names is for descriptive purposes only and does not imply endorsement by the U.S. Government.

Although this information product, for the most part, is in the public domain, it also may contain copyrighted materials as noted in the text. Permission to reproduce copyrighted items must be secured from the copyright owner.

Suggested citation:

Marineau, M.D., and Wright, S.A, 2015, Storage capacity of the Fena Valley Reservoir, Guam, Mariana Islands, 2014: U.S. Geological Survey Scientific Investigations Report 2015-5128, 31 p., http://dx.doi.org/10.3133/sir20155128. 


\section{Acknowledgments}

In particular, we are grateful to Mr. Danny Dungca (Department of Public Works, Naval Facilities Engineering Command Marianas) for general logistics, access to the U.S. Navy Base and reservoir, and providing copies of pre-construction documents. We would also like to acknowledge the military personnel at the U.S. Navy Explosive Ordnance Disposal Mobile Unit 5 for providing safety support, the personnel at the Water and Environmental Research Institute of the Western Pacific at the University of Guam Marine Laboratory for use of their watercraft, and Mr. Thomas Torres (Department of Land Management, Government of Guam) for providing survey benchmark information and for locating and marking benchmarks outside of the Naval Base Guam Ordnance Annex. This study was part of the Strategic Environmental Research and Development Program Project Number RC-2340.

\section{Contents}

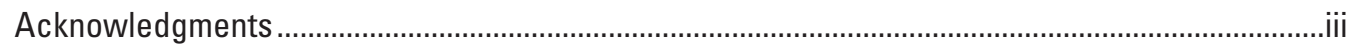

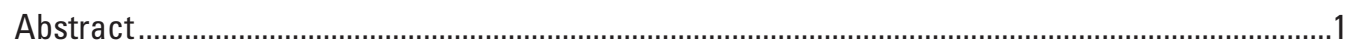

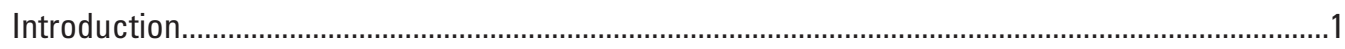

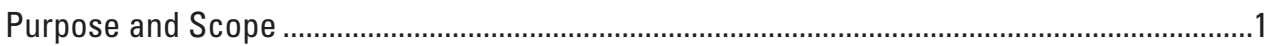

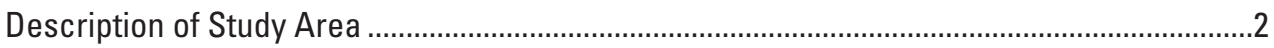

Previous Studies and Vertical Datum ................................................................................

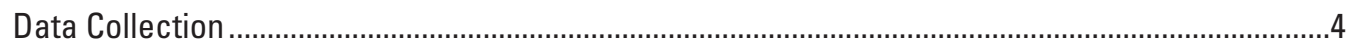

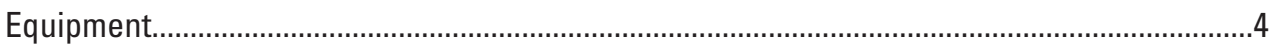

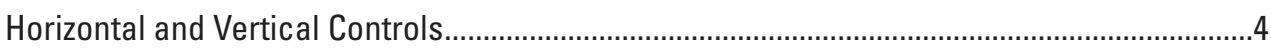

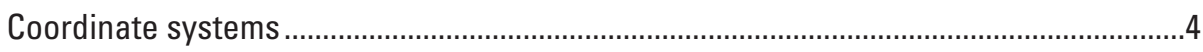

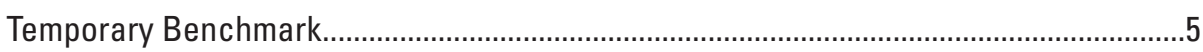

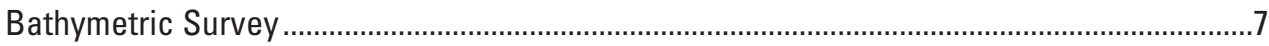

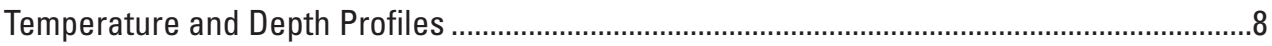

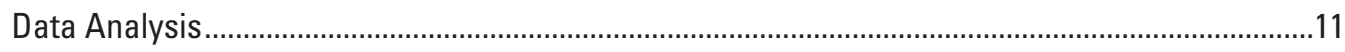

Shallow-Water Survey, Spillway Elevation, and Shoreline Digitization ..................................11

Sound-Speed Corrections ...................................................................................................11

Bed-Elevation Calculation from Depth Soundings ................................................................11

Digital Elevation Model Development .......................................................................................13

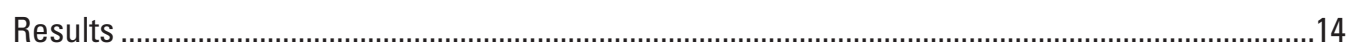

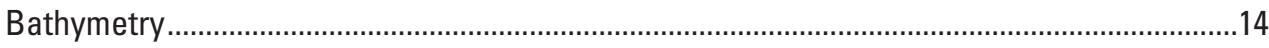

Reservoir Storage Capacity ..............................................................................................

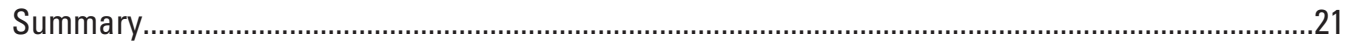

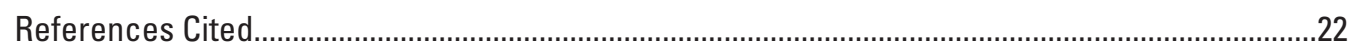

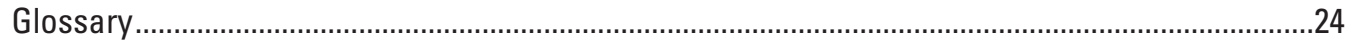

Appendix. National Geodetic Survey Datasheets .....................................................................25

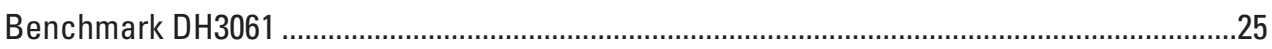

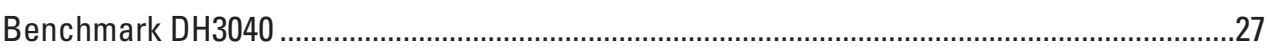

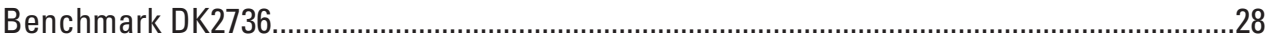

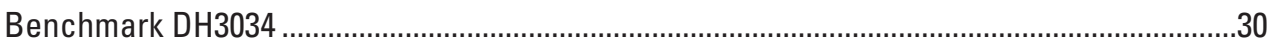




\section{Figures}

1. Map showing the Fena Valley Reservoir and watershed, Guam.

2. Photographs showing temporary benchmark USGS-BM1, installed February 21, 2014, near the boat launch area of the Fena Valley Reservoir, Guam.

3. Photograph showing the spillway at the Fena Valley Reservoir, Guam .6

4. Map showing the bathymetric boat-survey track, locations of topographic survey points at Imong River and Imong River Delta, and locations of conductivity, temperature, and depth (CTD) vertical profiles, Fena Valley Reservoir, Guam, 2014 ........9

5. Photograph showing sand deposition at Imong River Delta on the southern-most tip of the Fena Valley Reservoir, Guam .....

6. Photograph showing surveying of the Imong River between the Fena Valley Reservoir and the Imong River streamgage (station 16847000), Guam ... 10

7. Graphs showing examples of water temperature, salinity, density, and soundspeed profiles at three locations within the reservoir: $A$ and $B$, cast from the downstream part of the reservoir near the dam (depth, 20.4 meters, 66.9 feet); $C$ and $D$, cast from the middle part of the reservoir (depth, 12.5 meters, 41.0 feet); and $E$ and $F$, cast from the upstream part of the reservoir (depth, 7.0 meters, 23 feet)

8. Graph showing maximum depths measured using the CastAway Conductivity, Temperature, and Depth profiler in relation to depths derived from the digital elevation model of the Fena Valley Reservoir, Guam, 2014.

9. Map showing bathymetry and 5-foot interval contours, based on the February 2014 survey, Fena Valley Reservoir, Guam.

10. Graphs showing A, stage-surface area curves for 1951 and 2014; and B, stagecapacity curves with live and dead storage capacity in 1951 and 2014 indicated, Fena Valley Reservoir, Guam

\section{Tables}

1. Survey results for benchmarks used in the February 22, 2014, control survey from Talofofo Bay to Fena Valley Reservoir, Guam

2. Differences between published coordinates and 2014 surveyed coordinates, Fena Valley Reservoir, Guam

3. Rating table for surface area of the Fena Valley Reservoir, Guam, 2014 ..........................16

4. Rating table for storage capacity of the Fena Valley Reservoir, Guam, 2014 ..................18 


\section{Conversion Factors}

Inch/Pound to International System of Units

\begin{tabular}{|c|c|c|}
\hline Multiply & By & To obtain \\
\hline \multicolumn{3}{|c|}{ Length } \\
\hline inch (in.) & 2.54 & centimeter $(\mathrm{cm})$ \\
\hline foot (ft) & 0.3048 & $\operatorname{meter}(\mathrm{m})$ \\
\hline mile (mi) & 1.609 & kilometer (km) \\
\hline \multicolumn{3}{|c|}{ Area } \\
\hline acre & 4,047 & square meter $\left(\mathrm{m}^{2}\right)$ \\
\hline square foot $\left(\mathrm{ft}^{2}\right)$ & 0.09290 & square meter $\left(\mathrm{m}^{2}\right)$ \\
\hline square mile $\left(\mathrm{mi}^{2}\right)$ & 2.590 & square kilometer $\left(\mathrm{km}^{2}\right)$ \\
\hline \multicolumn{3}{|c|}{ Volume } \\
\hline acre-foot (acre-ft) & 1,233 & cubic meter $\left(\mathrm{m}^{3}\right)$ \\
\hline acre-foot (acre-ft) & 0.001233 & cubic hectometer $\left(\mathrm{hm}^{3}\right)$ \\
\hline \multicolumn{3}{|c|}{ Flow rate } \\
\hline acre-foot per year (acre-ft/yr) & 1,233 & cubic meter per year $\left(\mathrm{m}^{3} / \mathrm{yr}\right)$ \\
\hline foot per second $(\mathrm{ft} / \mathrm{s})$ & 0.3048 & meter per second $(\mathrm{m} / \mathrm{s})$ \\
\hline
\end{tabular}

Temperature in degrees Fahrenheit $\left({ }^{\circ} \mathrm{F}\right)$ may be converted to degrees Celsius $\left({ }^{\circ} \mathrm{C}\right)$ as ${ }^{\circ} \mathrm{C}=\left({ }^{\circ} \mathrm{F}-32\right) / 1.8$.

\section{Datums}

Vertical coordinate information is referenced to the 2004 Vertical Datum of Guam (GUVD04), which is referenced to the Mean Sea Level (MSL) calculated from the National Tidal Datum Epoch (NTDE) of 1983-2001 by Carlson and others (2009).

Previous datums used in historical surveys referenced elevation to the MSL tidal datum or to the mean lower low water (MLLW) tidal datum, although details on the precise elevation of the tidal datums used in the historical surveys is unknown.

Horizontal coordinate information is referenced to the North American Datum of 1983 (NAD 83) coordinates where the reference frame has been affixed to the stable Mariana tectonic plate [NAD 83(MA11)] (National Geodetic Survey, 2011).

Elevation, as used in this report, refers to distance above the vertical datum. 


\section{Abbreviations}

$\begin{array}{ll}\text { ADCP } & \text { Acoustic Doppler Current Profiler } \\ \text { CTD } & \text { Conductivity, temperature, and depth } \\ \text { DEM } & \text { Digital Elevation Model } \\ \text { GNSS } & \text { Global Navigation Satellite System } \\ \text { GUVD04 } & \text { Guam Vertical Datum of } 2004 \\ \text { MLLW } & \text { Mean Lower Low Water } \\ \text { MSL } & \text { Mean Sea Level } \\ \text { NTDE } & \text { National Tidal Datum Epoch } \\ \text { NAD83(MA11) } & \text { North American Datum of } 1983 \text { (referenced to the Mariana tectonic plate) } \\ \text { PSS-78 } & \text { Practical salinity scale } \\ \text { RTK } & \text { Real-time kinematic } \\ \text { SERDP } & \text { Strategic Environmental Research and Development Program } \\ \text { USGS } & \text { U.S. Geological Survey } \\ \text { UHF } & \text { Ultra-high frequency }\end{array}$




\title{
Storage Capacity of the Fena Valley Reservoir, Guam, Mariana Islands, 2014
}

\author{
By Mathieu D. Marineau and Scott A. Wright
}

\section{Abstract}

The Fena Valley Reservoir is in southern Guam and is the primary source of water for the U.S. Naval Base Guam and nearby village residents. Since the construction of the Fena Dam in 1951, sediment has accumulated in the reservoir and reduced its storage capacity. The reservoir was surveyed previously in 1973, 1979, and 1990 to estimate the loss in storage capacity. To determine the current storage capacity, the U.S. Geological Survey, in cooperation with the U.S. Department of Defense Strategic Environmental Research and Development Program, surveyed the bathymetry of the reservoir in February 2014.

The bathymetric survey was accomplished by making depth soundings using a boat-mounted, acoustic Doppler current profiler. Location during bathymetric data collection was determined using a single-base Global Navigation Satellite System-Real Time Kinematic survey. Vertical profiles of conductivity, temperature, and depth were collected periodically. The conductivity, temperature, and depth profiles were used to spatially and temporally adjust the sound-speed calculations used to determine depth from the soundings. Approximately 108 kilometers of transects with a total of about 380,000 depth soundings were surveyed. In addition, approximately 2,100 topographic survey points in shallow, wadable areas near the Imong River Delta were defined by using a Global Navigation Satellite System receiver attached to a fixed-length survey rod. Depth soundings and topographic survey points were compiled and interpolated to generate a digital-elevation model of the reservoir. Data extracted from the digital-elevation model were then tabulated to determine total reservoir capacity and create reservoir stage-surface area and stage-storage capacity tables.

Analyses of the bathymetric data indicate that the reservoir currently has 6,915 acre-feet of storage capacity. The engineering drawings of record show that the total reservoir capacity in 1951 was estimated to be 8,365 acre-feet. Thus, between 1951 and 2014, the total storage capacity decreased by 1,450 acre-feet (a loss of 17 percent of the original total storage capacity). The remaining live-storage capacity, or the volume of storage above the lowest-level reservoir outlet elevation, was calculated to be 5,511 acre-feet in 2014, indicating a decrease of 372 acre-feet (or 6 percent) of the original 5,883 acre-feet of live-storage capacity. The remaining dead-storage capacity, or volume of storage below the lowest-level outlet, was 1,404 acre-feet in 2014, indicating a decrease of 1,078 acre-feet (or 43 percent) of the original 2,482 acre-feet of dead-storage capacity.

\section{Introduction}

Fena Valley Reservoir, located in southern Guam, is owned and operated by the U.S. Navy. Construction of the Fena Dam began in 1950 and was completed in 1951. Previous surveys reveal a general decline in the Fena Valley Reservoir storage capacity. The U.S. Geological Survey (USGS), in cooperation with the U.S. Department of Defense Strategic Environmental Research and Development Program (SERDP), is investigating the potential effects of climate change on the water resources of Guam. In order to accurately predict surface-water availability by using a watershed model of southern Guam and a water-balance model of the reservoir, up-to-date reservoir capacity information is needed. The need for updated reservoir capacity data and the concern for reservoir sedimentation led to the initiation of this study.

\section{Purpose and Scope}

The USGS, in cooperation with the SERDP, conducted a bathymetric survey to determine the present storage capacity of the Fena Valley Reservoir and provide updated reservoir stage-surface-area and stage-capacity curves.

The bathymetric survey was part of a more comprehensive study to investigate the effects of climate change on the water resources of Guam. Some of the other parts of the comprehensive study include downscaling climate projections, developing an updated watershed model for the island, and developing a quantitative assessment of how future changes in streamflow and sediment loads will affect the reservoir. 
In this report, the stage-storage and stage-capacity results from the 2014 reservoir capacity survey were compared with those from the 1949 pre-construction survey to provide some general context of the quantity of sediment that has been deposited in the reservoir since construction. A detailed interpretation of sedimentation rates and deposition patterns is not included in this report.

\section{Description of Study Area}

The Fena Valley Reservoir is in southern Guam, $8.7 \mathrm{mi}$ southwest of the capitol, Hagåtña, at approximately $13^{\circ} 21^{\prime} \mathrm{N}$, $144^{\circ} 42^{\prime} \mathrm{E}$ and lies within the Naval Base Guam Ordnance Annex (formerly the Naval Magazine), which is one of many facilities that are a part of Naval Base Guam, a consolidated U.S. Navy installation. At full capacity, the reservoir surface area extends approximately 0.30 square miles $\left(\mathrm{mi}^{2}\right)$ and drains a watershed area of about $5.88 \mathrm{mi}^{2}$. The reservoir was formed after the construction of the Fena Dam in 1951 and inundation of the Fena River Valley. The earthen dam is 85 feet (ft) tall and 1,050 ft in length. The reservoir currently serves as the primary source of water for Navy Base Guam and the civilian residents living in villages near the base in southern Guam. At the time of construction, the reservoir had an estimated total storage capacity of 8,365 acre-feet (acre-ft; based on digitization of 1949 stage-capacity curve from Frederic R. Harris, Inc., 1949). Live storage, sometimes called usable storage or water-supply storage, is water storage located above the lowest-level outlet, which is $37.00 \mathrm{ft}$ below the spillway crest (Frederic R. Harris, Inc., 1949). The live-storage capacity at the time of construction was estimated to be 5,883 acre-ft. The 2,482 acre-ft of 1949 storage volume below the lowestlevel outlet is considered dead storage and is reserved for siltation.

Climate in Guam is characterized as warm and humid. Mean temperature is 84 degrees Fahrenheit $\left({ }^{\circ} \mathrm{F}\right)$ and generally ranges from 79 to $89^{\circ} \mathrm{F}$ (National Oceanic and Atmospheric Administration, 2014). Average annual precipitation is approximately 100 inches in southern Guam (Shade, 1983). Most of this precipitation falls between July and November; December through June is considered the dry season. Typhoons and tropical storms happen periodically and can deliver substantial amounts of precipitation in 24- to 48-hour periods.

The geology in the Fena Valley Watershed consists mostly of rocks in the Umatac Formation (primarily weathered rock of volcanic origin) and an older limestone formation in the higher elevations (Tracey and others, 1964). The surficial geology in the western-most part of the watershed appears to have high permeability (evidenced by the lack of any large surface-water features). Precipitation in this region seeps into the soil and underlying rock until it reaches the Umatac Formation, which has low permeability (Ward and others, 1965). The precipitation then resurfaces through springs that are found in the area of Fena Valley Reservoir. Although there are a few roads and facilities in the watershed, it remains largely undeveloped and covered with tall grasses and broad-leaf forests. The volcanic soils are highly erodible when denuded of vegetation (Kennedy Engineers Inc., 1973). Previous studies noted that wildfires (Shade, 1983; Nakama 1992) and fires started by poachers (Kennedy Engineers Inc., 1973) are common during the dry season and indicated that they are the primary underlying cause of erosion. During the survey, no direct evidence of wildfires was observed; however, several areas of recent soil erosion, in the form of translational earth slides, were noted on the steep slopes. The steep slopes are particularly vulnerable to this type of erosion (Schumm and Harvey, 2008), which could be triggered by saturated soil conditions following intense precipitation (Highland and Bobrowsky, 2008).

Three rivers drain into the reservoir from the south and west: the Imong, Almagosa, and Maulap Rivers (fig. 1). Streamflow discharge on all three of these rivers is monitored by USGS streamgages (station 16847000, Imong River near Agat; station 16848100, Almagosa River near Agat Guam; station 16848500, Maulup River near Agat Guam; fig. 1). The watershed draining to the reservoir does not extend far to the east, and there are no major tributary rivers on the east side. Water exiting the reservoir over the spillway enters the Maagas River and eventually drains east to the Pacific Ocean.

\section{Previous Studies and Vertical Datum}

The Fena Valley Reservoir was surveyed previously in 1973, 1979, and 1990 (Kennedy Engineers Inc., 1973; Curtis, 1984; Nakama, 1992, respectively) to determine the remaining storage capacity and estimate sedimentation rates. Previous surveys show a general but unsteady decline in the Fena Valley Reservoir storage capacity since completion of the dam in 1951.

The current official vertical datum is the Guam Vertical Datum 2004 (GUVD04); however, the dam construction predates this datum by several decades. Previous studies and the pre-construction engineering drawings of record used a variety of datums or did not indicate a datum. For example, the engineering drawings of record note that elevations were "corrected" to Mean Lower Low Water (MLLW) and designated MLLW as the elevation datum on one sheet; the vertical datum was not indicated on other sheets (Frederic R. Harris, Inc., 1949). Later studies either did not indicate a datum (Kennedy Engineers Inc., 1973) or used Mean Sea Level (MSL; Curtis, 1984; Nakama, 1992). In all cases, the same elevation of the spillway $(111.35 \mathrm{ft})$ was reported but without referencing this elevation to a consistent datum. The original elevation measurement of the spillway crest was likely an error caused by using an unofficial MLLW datum, and that error has propagated through subsequent studies and local surveys. 
$144^{\circ} 42^{\prime} \mathrm{E}$

$144^{\circ} 42^{\prime} 30^{\prime \prime} \mathrm{E}$

$144^{\circ} 43^{\prime} \mathrm{E}$

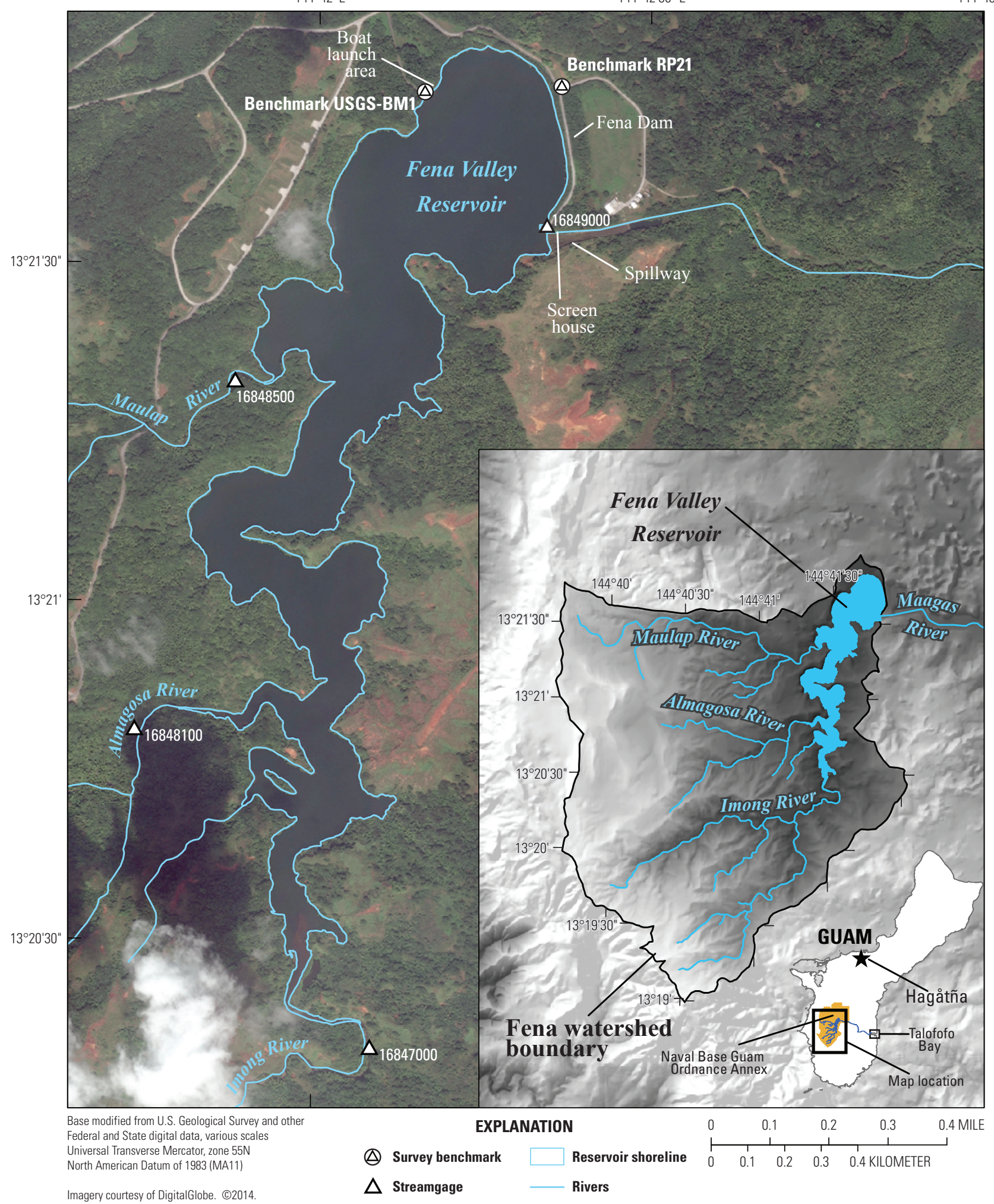

10-meter Digital Elevation Map from Guam Coastal Atlas

(http://www.guammarinelab.com/)

Figure 1. Fena Valley Reservoir and watershed, Guam. 
During this study (2014), a control survey using the latest survey techniques was conducted to directly relate the elevation of the Fena Dam spillway crest to GUVD04 vertical datum (Carlson and others, 2009). The results of the spillway elevation differed from that reported in previous studies. Although there are several possible causes of survey error, the original survey also referenced an unofficial tidal datum. Tidal records from a specific 19-year period designated as a National Tidal Datum Epoch (NTDE) are required to compute tidal datums reliably (Gill and Schultz, 2001). Because the first known tidal station on Guam was not established until 1948 (Department of Commerce, 1948), tidal records were not long enough at the time of reservoir construction to compute official tidal datums. Because there are no other known control surveys relating the spillway crest to GUVD04 or any other known benchmark, in this report only the results of the control survey conducted during this study are used. The precise elevation of the spillway, however, does not affect the capacity calculations of this study or previous studies since they all measure reservoir capacity relative to the spillway crest.

\section{Data Collection}

The equipment and methods used to collect the topographic and bathymetric data, which were used to calculate the reservoir storage capacity, are described in this section. All fieldwork was conducted during February 22-27, 2014.

\section{Equipment}

The following is a list of equipment used during the bathymetric survey and establishment of a temporary benchmark.

- 14-ft McKee Craft fiberglass boat with 4-horsepower engine

- Sontek M9 HydroSurveyor ${ }^{\mathrm{TM}}$ acoustic Doppler current profiler (ADCP)
- Field laptop with Sontek HydroSurveyor ${ }^{\mathrm{TM}}$ software

- Trimble R7 Global Navigation Satellite System (GNSS) receiver, Ultra-High Frequency (UHF) radio, and Zephyr II antenna mounted to an adjustable-height tripod

- Trimble R10 GNSS receiver used as a rover mounted to the boat or used with a 2-meter fixed-length survey rod

- Trimble TSC3 hand-held controller, used to program the GNSS receivers and record data

- Sontek CastAway ${ }^{\mathrm{TM}}$ conductivity, temperature, and depth (CTD) profiler

\section{Horizontal and Vertical Controls}

A temporary benchmark was established near the reservoir and used for horizontal and vertical control during this study. This section describes the coordinate systems used in this survey and the methods used to establish the temporary benchmark.

\section{Coordinate systems}

The vertical coordinate system used in this study is the Guam Vertical Datum of 2004 (GUVD04). GUVD04 is referenced to the MSL calculated from the NTDE of 19832001 (Carlson and others, 2009). The horizontal geographic coordinate system used is the North American Datum of 1983 adjusted by the National Geodetic Survey such that it is referenced to the Mariana tectonic plate; it is abbreviated as NAD83(MA11). NAD83(MA11) is used to define coordinates for Guam and the Northern Mariana Islands (National Geodetic Survey, 2011). The projected coordinate system used in figures in this report is NAD83(MA11) Universal Transverse Mercator zone 55 North. 


\section{Temporary Benchmark}

The primary benchmark used for horizontal and vertical control at the Fena Dam is benchmark RP21 (fig. 1; Chui Yueng, U.S. Geological Survey, written commun., 2014; fig. 1). However, benchmark RP21 is not readily accessible from the boat launch area and is located below power lines, which can affect GNSS quality and distort measurements (Rydland and Densmore, 2012). In addition, surveymeasurement quality information on benchmark RP21 was not well documented. Therefore, a temporary benchmark (designated USGS-BM1) was installed near the boat launch area at the northwestern corner of the reservoir (fig. 1). Horizontal and vertical controls for the bathymetric survey were established by surveying from Guam Department of Land Management (Guam DLM) Benchmark DH3061 (appendix 1; DH3061 is not shown in a figure), using a Level IV (Rydland and Densmore, 2012) single-base global navigation satellite system, real-time kinematics (GNSSRTK) survey, to temporary benchmark USGS-BM1 (fig. 1). Guam DLM Benchmark DH3061 was selected because of its proximity to the reservoir and because it was surveyed by Carlson and others (2009) during the establishment of GUVD04.

Temporary benchmark USGS-BM1 was installed February 21, 2014, and marked by a USGS brass plate (fig. 2). The asphalt surface of the boat launch parking lot was buried by about 6 inches of soil. To secure the brass plate, a 12-inch diameter hole was dug though the soil to the asphalt and backfilled with quick-setting concrete mix. The brass plate was installed in the concrete (fig. 2). Horizontal and vertical coordinates of temporary benchmark USGS-BM1 and other
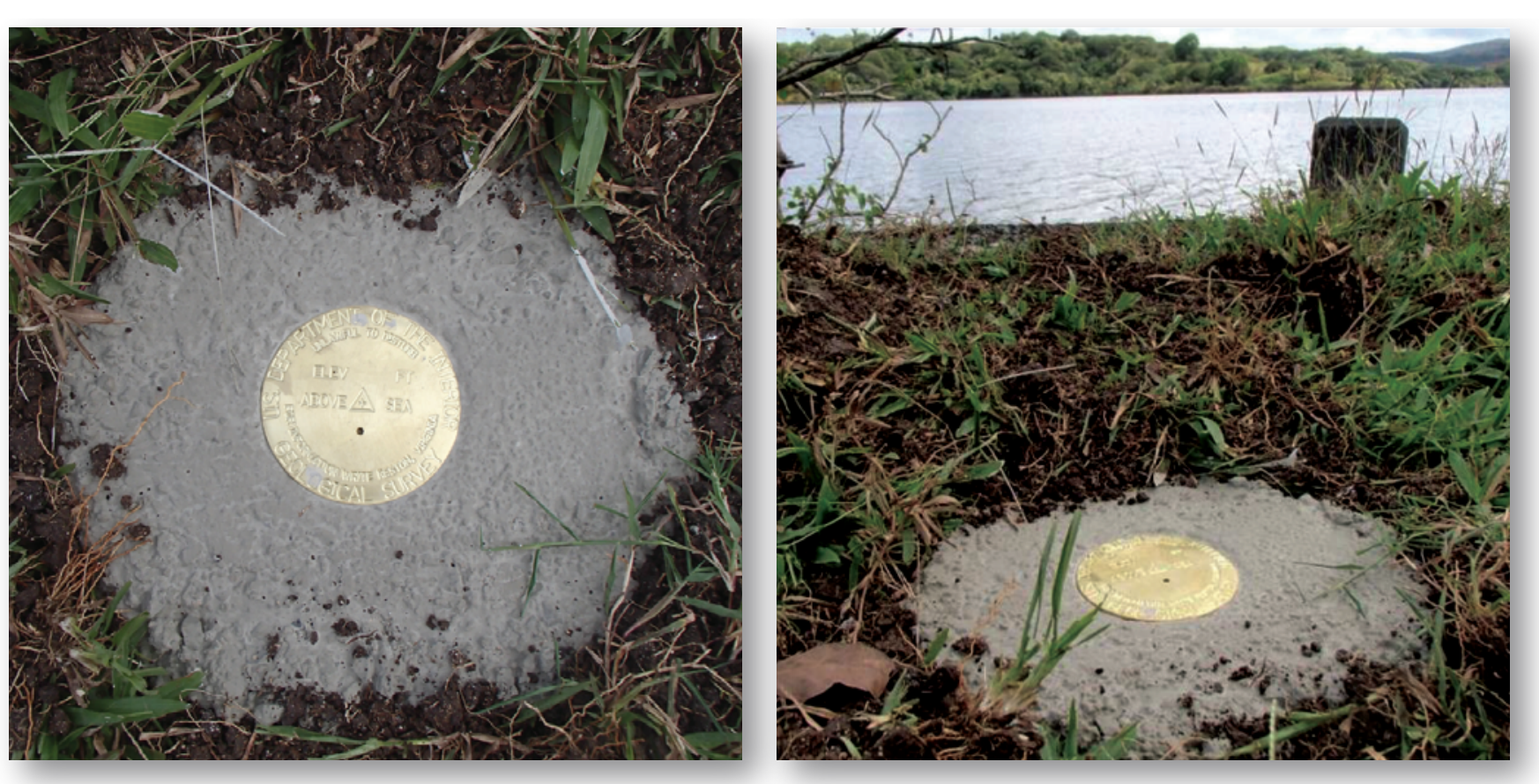

measurements with occupation times typically between 10 and 40 seconds.

The GNSS-RTK base station consisted of a Trimble R7 GNSS receiver with a dual frequency, Zephyr II antenna and UHF transmitting radio mounted on an adjustable height tripod. A laser tribrach was used to center the base station antenna above a benchmark. Each leg of the tripod was braced by sand bags to prevent movement during the survey. The rover consisted of a Trimble R10 Global GNSS receiver mounted to a 2-meter fixed-height survey rod. Data were logged on a Trimble TSC3 hand-held controller using Trimble Access Software (Trimble, 2013).

While the GNSS-RTK base station was set up on Guam DLM Benchmark DH3061 for the survey to temporary benchmark USGS-BM1, three nearby benchmarks (DH3034, DK2736, and DH3040; appendix 1) were surveyed as vertical and horizontal checks. Later, the GNSS-RTK base station was set over temporary benchmark USGS-BM1to perform elevation checks at additional benchmarks and to perform a single-base GNSS-RTK survey of the reservoir. Elevation checks were done for two additional benchmarks (GGN 2053 and GGN 2054; table 1), which are outside of the Naval Base Guam Ordnance Annex near the entrance gate (Thomas Torres, Government of Guam, written commun., 2014). In addition, survey measurements were collected for benchmark RP21 (fig. 1) and the spillway crest (fig. 3).

Horizontal and vertical coordinates for each benchmark and the spillway crest are listed in table 1. Differences between previously published coordinates and the coordinates of survey measurements made during this study are listed in table 2.

Figure 2. Temporary benchmark USGS-BM1, installed February 21, 2014, near the boat launch area of the Fena Valley Reservoir, Guam. (Photographs by M.D. Marineau, February 22, 2014) 
Table 1. Survey results for benchmarks used in the February 22, 2014, control survey from Talofofo Bay to Fena Valley Reservoir, Guam.

\begin{tabular}{lcccc}
\hline $\begin{array}{c}\text { Benchmark/ } \\
\text { survey point }\end{array}$ & Latitude $^{1}$ & Longitude $^{\prime}$ & $\begin{array}{c}\text { Ellipsoid height } \\
\text { (feet) }\end{array}$ & $\begin{array}{c}\text { Orthometric height }^{{ }^{3}} \\
\text { (feet) }\end{array}$ \\
\hline DH3040 & $13^{\circ} 21^{\prime} 00.33332^{\prime \prime} \mathrm{N}$ & $144^{\circ} 46^{\prime} 09.66726^{\prime \prime} \mathrm{E}$ & 216.47 & 40.84 \\
DK2736 & $13^{\circ} 20^{\prime} 32.74334^{\prime \prime} \mathrm{N}$ & $144^{\circ} 45^{\prime} 44.64012^{\prime \prime} \mathrm{E}$ & 189.55 & 14.2 \\
DH3034 & $13^{\circ} 20^{\prime} 10.72125^{\prime \prime} \mathrm{N}$ & $144^{\circ} 45^{\prime} 44.64012^{\prime \prime} \mathrm{E}$ & 184.25 & 8.8 \\
USGS BM1 & $13^{\circ} 21^{\prime} 45.11828^{\prime \prime} \mathrm{N}$ & $144^{\circ} 42^{\prime} 09.96910^{\prime \prime} \mathrm{E}$ & 289.97 & 112.69 \\
GGN 2053 & $13^{\circ} 23^{\prime} 19.11545^{\prime \prime} \mathrm{N}$ & $144^{\circ} 41^{\prime} 13.24816^{\prime \prime} \mathrm{E}$ & 576.83 & 399 \\
GGN 2054 & $13^{\circ} 23^{\prime} 12.01057^{\prime \prime} \mathrm{N}$ & $144^{\circ} 41^{\prime} 07.84761^{\prime \prime} \mathrm{E}$ & 558.63 & 380.83 \\
RP21 & $13^{\circ} 21^{\prime} 46.35849^{\prime \prime} \mathrm{N}$ & $144^{\circ} 42^{\prime} 21.74374^{\prime \prime} \mathrm{E}$ & 302.63 & 125.41 \\
Spillway Crest & $13^{\circ} 21^{\prime} 32.38333^{\prime \prime} \mathrm{N}$ & $144^{\circ} 42^{\prime} 20.82923^{\prime \prime} \mathrm{E}$ & 287.77 & 110.63 \\
Spillway Crest ${ }^{5}$ & $13^{\circ} 21^{\prime} 31.86879^{\prime \prime} \mathrm{N}$ & $144^{\circ} 42^{\prime} 20.94531^{\prime \prime} \mathrm{E}$ & 288.07 & 110.93 \\
\hline
\end{tabular}

${ }^{1}$ Symbols and letters ${ }^{\circ}$, , $^{\prime}, \mathrm{N}$, and $\mathrm{E}$ refer to degrees, minutes, seconds, north and east, respectively.

${ }^{2}$ Ellipsoid height referenced to North American Datum of 1983 (NAD83) referenced to the Mariana tectonic plate.

${ }^{3}$ Orthometric height referenced to Guam Vertical Datum of 2004 (GUVD04) using GEOID12A (National Geodetic Survey, 2012).

${ }^{4}$ Survey measurement at the northern end of the spillway crest.

${ }^{5}$ Survey measurement at the center of the spillway crest.

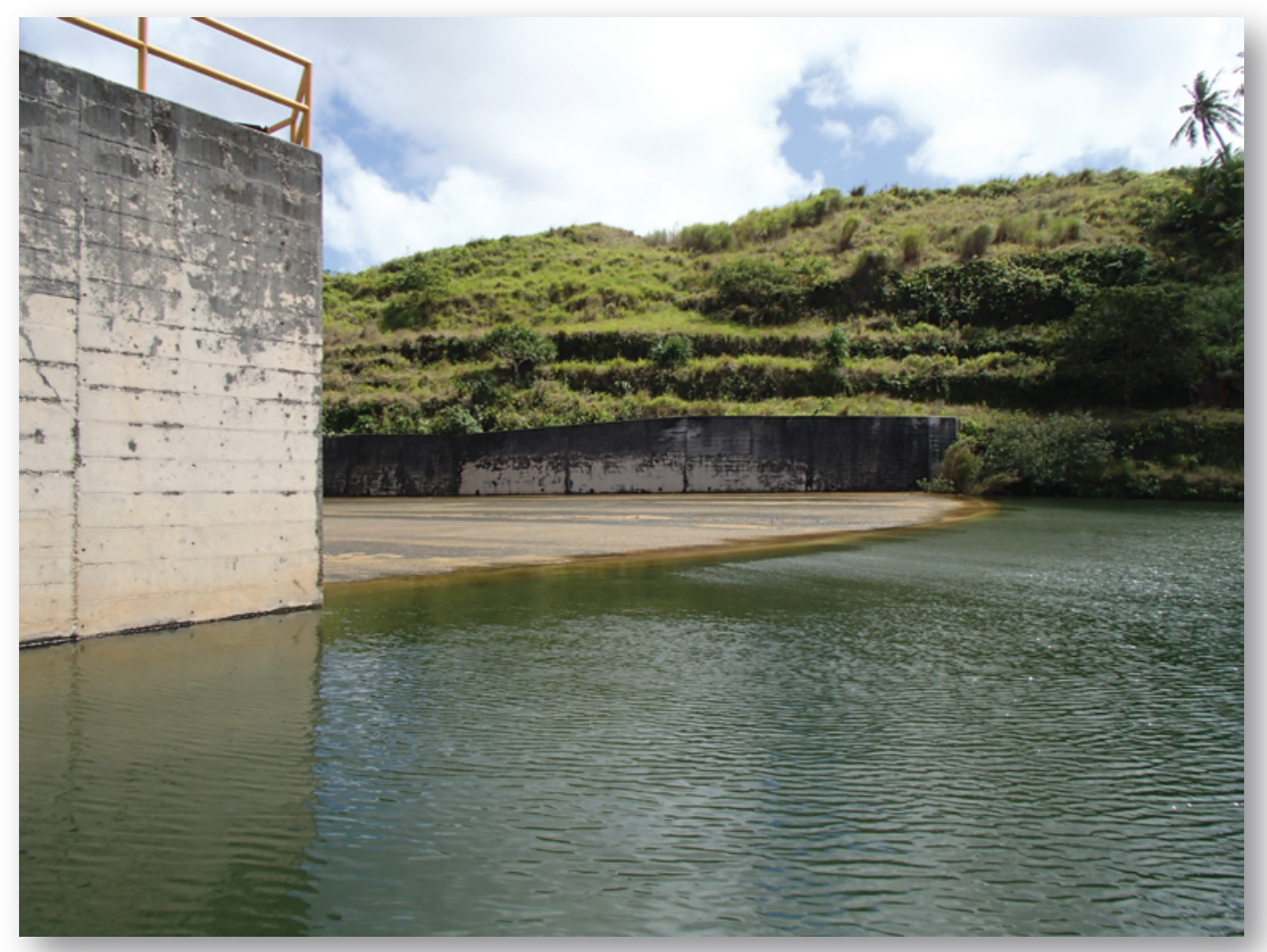

Figure 3. Spillway at the Fena Valley Reservoir, Guam. (Photograph by M.D. Marineau, February 21, 2014) 
Table 2. Differences between published coordinates and 2014 surveyed coordinates, Fena Valley Reservoir, Guam.

[ft, feet; MSL, mean sea level; n/a, published coordinates were not available for comparison; NGS, National Geodetic Survey. Difference is published minus surveyed coordinates.]

\begin{tabular}{|c|c|c|c|c|}
\hline $\begin{array}{l}\text { Benchmark/ } \\
\text { survey point }\end{array}$ & $\begin{array}{l}\text { Latitude } \\
\text { difference }^{1}\end{array}$ & $\begin{array}{l}\text { Longitude } \\
\text { difference }^{1}\end{array}$ & $\begin{array}{l}\text { Orthometric height difference }{ }^{2} \\
\text { (ft) }\end{array}$ & $\begin{array}{c}\text { Source of } \\
\text { published data }\end{array}$ \\
\hline DH3040 & $\mathrm{n} / \mathrm{a}$ & $\mathrm{n} / \mathrm{a}$ & -0.28 & NGS datasheet \\
\hline DH3034 & $\mathrm{n} / \mathrm{a}$ & $\mathrm{n} / \mathrm{a}$ & -0.11 & NGS datasheet \\
\hline GGN 2053 & $00^{\circ} 00^{\prime} 0.00886^{\prime \prime}$ & $00^{\circ} 00^{\prime} 0.01389^{\prime \prime}$ & -0.05 & Written communication ${ }^{3}$ \\
\hline Spillway crest ${ }^{5}$ & $\mathrm{n} / \mathrm{a}$ & $\mathrm{n} / \mathrm{a}$ & 0.72 & Written communication ${ }^{4}$ \\
\hline Spillway crest ${ }^{6}$ & $\mathrm{n} / \mathrm{a}$ & $\mathrm{n} / \mathrm{a}$ & 0.42 & Written communication ${ }^{4}$ \\
\hline
\end{tabular}

${ }^{1}$ Symbols and letters: ${ }^{\circ},{ }^{\prime}$, and ", refer to degrees, minutes, seconds, respectively.

${ }^{2}$ Orthometric height referenced to Guam Vertical Datum of 2004 (GUVD04) using GEOID12A (National Geodetic Survey, 2012); NGS datasheets are included in the appendix.

${ }^{3}$ Thomas Torres, Government of Guam, written commun., 2014.

${ }^{4}$ Elevation of RP21, $125.83 \mathrm{ft}$ above MSL; spillway crest elevation, $111.35 \mathrm{ft}$ above MSL (Ron Rickman and Chui Yueng, U.S. Geological Survey, written commun., 2014).

${ }^{5}$ Survey measurement at northern end of Spillway Crest.

${ }^{6}$ Survey measurement at center of Spillway Crest.

A USGS streamgage at the spillway (station 16849000, Fena Dam Spillway near Agat, Guam; fig. 1) monitors reservoir stage and is referenced to the spillway crest. In general, during the 4 days of the bathymetric survey, the reservoir was full. The change in stage was approximately $0.16 \mathrm{ft}$.

\section{Bathymetric Survey}

Bathymetric data were collected using a boat-mounted Sontek M9 HydroSurveyor ${ }^{\mathrm{TM}}$ (M9) acoustic Doppler current profiler (ADCP). The ADCP was attached to the side of the 14-ft fiberglass McKee Craft motorized boat at a depth of $1.15 \mathrm{ft}$ (measured from the water surface to the bottom of the ADCP) using an aluminum mount and wooden frame.

The M9 is equipped with nine transducers. One of the transducers is pointed directly below the ADCP, and the other eight are arranged as two sets of four transducers in Janus configurations with each transducer at a 25-degree slant angle. The center transducer $(0.5$ megahertz [MHz] $)$ is designed to measure depth directly beneath the instrument, and the two sets of transducers in Janus configurations (1 MHz and $3 \mathrm{MHz}$ ) are designed to measure three-dimensional velocity profiles. However, the angled transducers also record the depth to the bed such that the ADCP records five depth measurements per ping with the footprint dependent on water depth (larger footprint in deeper water). Internal compass data are used by the HydroSurveyor software (Sontek Inc., 2013) to horizontally locate the depths from the angled transducers with respect to instrument position. In addition to the horizontal position corrections, data from the pitch/roll sensor are used to make geometric corrections. During operation, the center transducer is always in use, whereas only one of the sets of four outer transducers is in use at any given time, depending on water depth and instrument settings. For depths up to 5 meters (m; about $16.4 \mathrm{ft}$ ), the $3.0 \mathrm{MHz}$ set of transducers is typically used, and for deeper waters (greater than $5 \mathrm{~m}$ ), the second set of transducers, operating at $1.0 \mathrm{MHz}$, is used. The instrument was set to automatically switch from one set of transducers to the other depending on the detected water depth. The maximum depth that the $1.0-\mathrm{MHz}$ transducers are capable of measuring is $40 \mathrm{~m}$ (about $130 \mathrm{ft}$ ). According to manufacturer specifications, the vertical accuracy of the M9 is $0.02 \mathrm{~m}(0.07 \mathrm{ft})$ when using sound-speed corrections (Xylem Inc., 2012a). System checks and compass calibration of the ADCP were performed daily.

Data were recorded on a field laptop using HydroSurveyor software. Location was determined using a single-base GNSS-RTK survey. A Trimble R10 GNSS receiver mounted to the boat was configured to provide a $10 \mathrm{~Hz}$ National Marine Electronics Association data stream of vector track and ground speed data and global positioning system fix information data to the HydroSurveyor ${ }^{\mathrm{rm}}$ software. The GNSS base station was mounted over benchmark USGS-BM1. The HydroSurveyor $^{\mathrm{TM}}$ software uses the coordinates from the R10 GNSS, ADCP heading information, and measured depth to calculate the precise position of each depth sounding. 
The approach for conducting the bathymetric survey was first to follow the entire shoreline as closely as possible, given dense vegetation and water depth. Distance to the shoreline was generally between 3 and $9 \mathrm{ft}$. After the shoreline depth data were collected, the center of the reservoir was surveyed by generally following a crisscross pattern (fig. 4). The real-time display of the boat position along with previously collected data on the field laptop were used to determine where to guide the boat to reduce data gaps. Deltaic deposits were found at the mouth of the Imong River (fig. 5). In these areas, the shallow water prevented use of the boat for surveying. Therefore, the R10 GNSS rover was used with a 2-m (6.56-ft) survey rod (fig. 6) to survey the Imong River and delta. An outline of the reservoir with the location of all depth soundings and topographic survey points is shown in figure 4.

\section{Temperature and Depth Profiles}

The density of water is primarily affected by temperature in freshwater reservoirs. Changes in the density above and below a thermocline will affect the speed of sound underwater (referred to as "sound speed"). Sound-speed variation in the water column, if uncorrected, can introduce error in depth measurements collected using acoustically based survey instruments. A $10^{\circ} \mathrm{F}$ decrease in temperature (from $65^{\circ} \mathrm{F}$ to $55^{\circ} \mathrm{F}$, for example) in freshwater can decrease the sound speed by about $54 \mathrm{ft}$ per second ( $\mathrm{ft} / \mathrm{s})$, or 1.1 percent, determined on the basis of calculations made using the Chen and Millero (1977) equation for sound speed. Thus, assuming the water column is the same temperature as the surface would cause an overestimate of sound speed leading to a biased-high estimate of depth (resulting in an overestimation of reservoir capacity). Most ADCPs are equipped with built-in temperature sensors that provide only near-surface temperature (Oberg and others, 2005). Vertical profiles of conductivity, temperature, and depth CTD (referred to as "casts") were collected using a Sontek CastAway ${ }^{\mathrm{TM}}$ CTD profiler and were used to calculate the sound speed throughout the water column. Generally, a cast was collected at the start of the survey, during the survey whenever moving to a new location, and at the end of the survey (fig. 4). The CastAway CTD has an internal Global Positioning System (GPS) receiver for measuring the horizontal location of each cast. The CastAway CTD can operate in depths up to $100 \mathrm{~m}$ (about $328.1 \mathrm{ft}$ ) with an error of \pm 0.25 percent full scale and temperatures ranging from -5 to $45^{\circ} \mathrm{C}$ (about 23 to $113^{\circ} \mathrm{F}$ ) with an error of $\pm 0.05^{\circ} \mathrm{C}$ (about $\pm 0.09^{\circ} \mathrm{F}$ ) (Yellow Springs Instruments, 2010). 


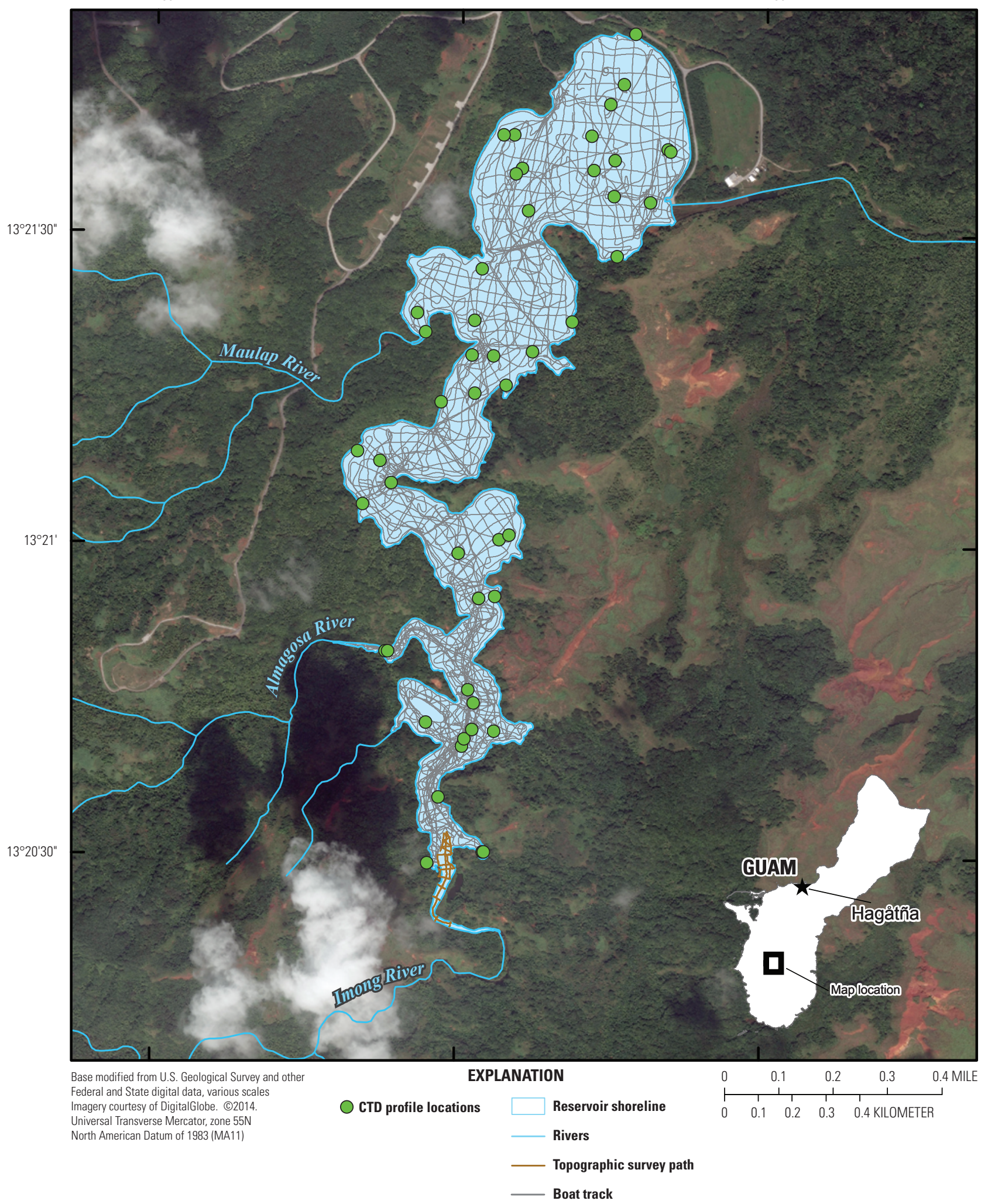

Figure 4. Bathymetric boat-survey track, locations of topographic survey points at Imong River and Imong River Delta, and locations of conductivity, temperature, and depth (CTD) vertical profiles, Fena Valley Reservoir, Guam, 2014. 


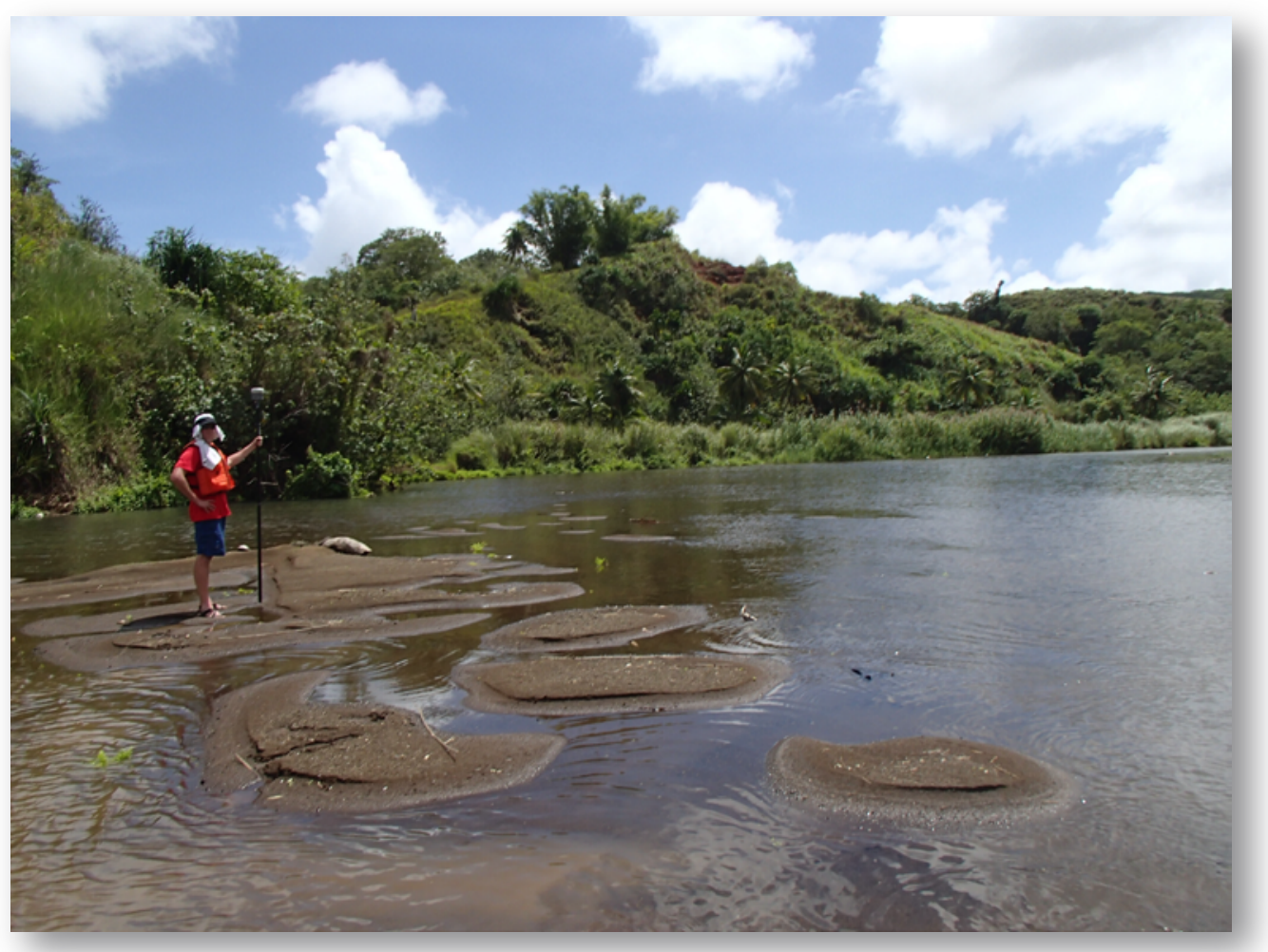

Figure 5. Sand deposition at Imong River Delta on the southern-most tip of the Fena Valley Reservoir, Guam. (Photograph by M.D. Marineau, February 25, 2014)

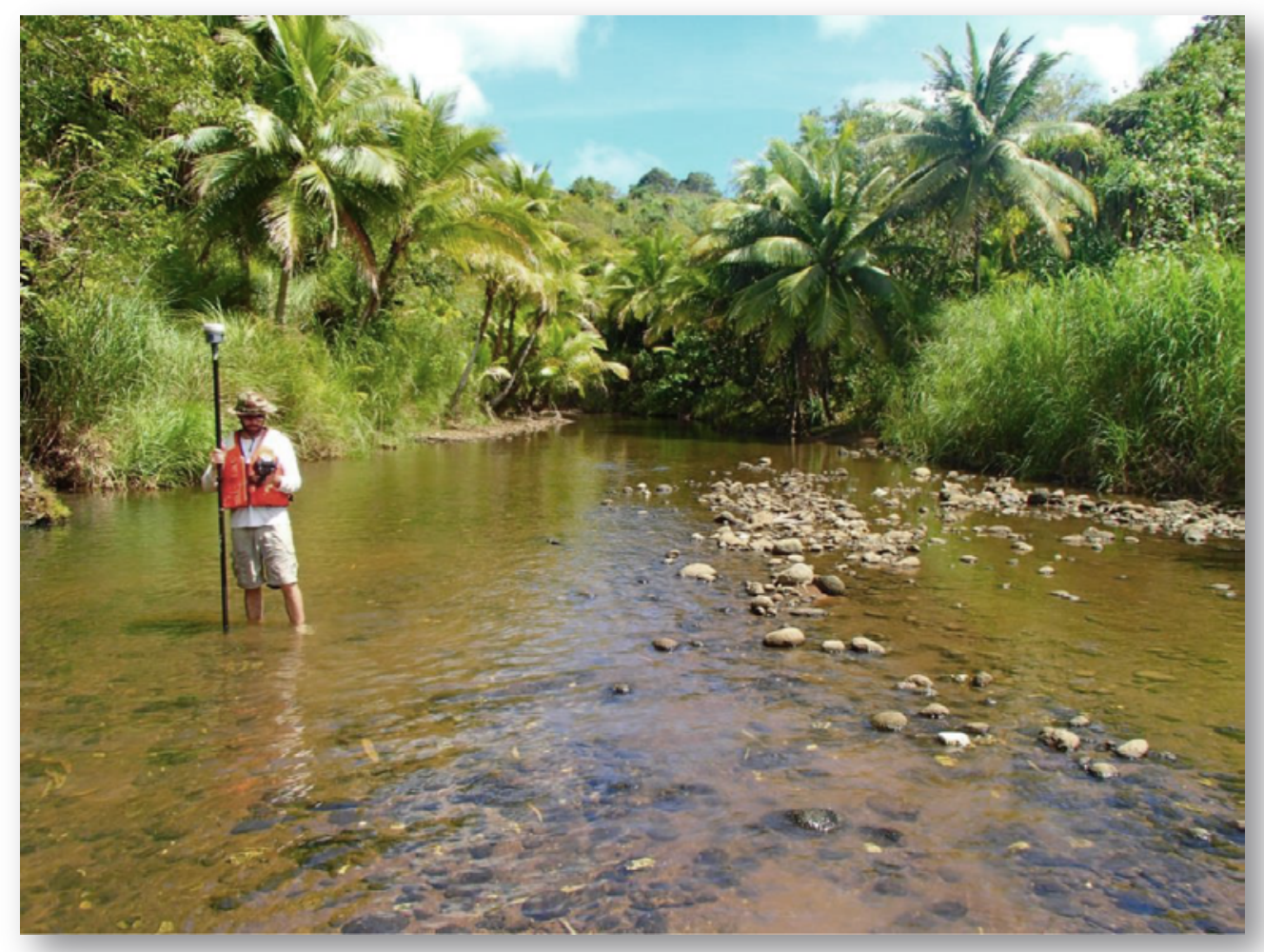

Figure 6. Surveying of the Imong River between the Fena Valley Reservoir and the Imong River streamgage (station 16847000), Guam. (Photograph by S.A. Wright, February 25, 2014) 


\section{Data Analysis}

Raw depth-sounding data were first corrected for changes in sound speed, resulting from potential thermoclines. The sound-speed corrected depth data were then converted to elevation and merged with topographic datasets and the shoreline data. The merged data were interpolated to obtain a 1-meter (3.28-ft) resolution digital elevation model (DEM) of the survey. This DEM was used to compute capacity.

\section{Shallow-Water Survey, Spillway Elevation, and Shoreline Digitization}

Additional shallow-water survey measurements were processed in Trimble Business Center software (Trimble, 2014). The coordinates of these points were then merged with bathymetric points. The spillway crest was also surveyed (tables 1 and 2) and found to have an average elevation of $110.8 \mathrm{ft}$ GUVD04.

The elevation of the spillway crest was surveyed by using a fixed-length survey rod with the $\mathrm{R} 10$ receiver. The spillway crest was surveyed in two locations, once near the northern wall of the spillway and once in the center of the spillway (tables 1 and 2). Results for these two spillway crest locations differed by about $0.3 \mathrm{ft}$, and neither corresponded with previously published survey elevations. The differences between the two survey elevations could be associated with multipath signals near the northern wall or could be due to difficulties in maintaining survey rod stability on the spillway crest. For this study, we averaged the two values and reported the surveyed elevation of the spillway crest as $110.8 \mathrm{ft}$ GUVD04.

The shoreline, representing spillway elevation, was digitized from high-resolution satellite imagery of the reservoir (fig. 1), dated February 7, 2014, courtesy of DigitalGlobe Inc. (2014). The imagery was collected when the reservoir was near full capacity, which was based on USGS streamgage measurements recorded at the time. The bathymetric data were overlaid and reviewed to ensure that all points fell within the digitized shoreline. The shoreline was then converted to points at 1-meter (3.28-ft) intervals using $\operatorname{ArcGIS}^{\mathrm{TM}}$, assigned an elevation of $110.8 \mathrm{ft}$ GUVD04 (elevation the water surface when reservoir is at full capacity), and merged with the bathymetric and topographic data.

\section{Sound-Speed Corrections}

The HydroSurveyor ${ }^{\mathrm{TM}}$ software integrates multiple measurements made using the CastAway ${ }^{\mathrm{TM}} \mathrm{CTD}$ with the bathymetric data. Sound speed was calculated by using the Chen and Millero (1977) equation, and beam angle changes resulting from the presence of a thermocline were corrected for by using Snell's Law (Joel Edelman, Sontek Inc., written commun., 2014). The HydroSurveyor software was used to apply sound-speed corrections to each depth sounding. Temperatures in the upper $10 \mathrm{ft}$ of the water column were fairly uniform at about $85^{\circ} \mathrm{F}$. Below $10 \mathrm{ft}$ to around $30 \mathrm{ft}$, temperatures dropped steadily to about $80^{\circ} \mathrm{F}$, indicating the presence of a thermocline. The average conductivity measured in the reservoir was 211 microsiemens per centimeter $(\mu \mathrm{S} / \mathrm{cm})$, and ranged from 176 to $260 \mu \mathrm{S} / \mathrm{cm}$. The peak in conductivity occurred right around the thermocline; however, these changes in conductivity were considered low and had very little effect on sound-speed calculations. Average sound speed, calculated from the CTD profiles, was 4,940 ft/s and ranged from 4,925 to $4,947 \mathrm{ft} / \mathrm{s}$. Examples of the water temperature, salinity, density and sound-speed profiles for three locations within the reservoir are shown in figure 7. The salinity in these plots is shown using the practical salinity scale (PSS-78), and the conversion of conductivity to salinity is based on the international equation of state for seawater (United Nations Educational, Scientific, and Cultural Organization, 1981). This conversion was performed internally by the CastAway CTD (Xylem, 2012b).

\section{Bed-Elevation Calculation from Depth Soundings}

After sound-speed corrections were applied to the depth soundings, the measurements from the depth soundings were converted to reservoir bed elevations on the basis of the reservoir stage at the time of measurement. Changes in stage can affect the capacity calculations if not properly taken into account. For example, during the time of the survey, the reservoir surface area at the spillway elevation was estimated as 192.6 acres (on the basis of the shoreline digitization), and the maximum observed range in stage was $0.16 \mathrm{ft}$. Failure to consider this change in stage could introduce error as high as 31 acre-ft in the storage-capacity estimate.

To account for the changes in stage, the corrected depth measurements were exported from the HydroSurveyor ${ }^{\mathrm{TM}}$ program to an Excel $^{\circledR}$ file (Microsoft Corp., 2010). The time stamp for each depth sounding was rounded to the nearest 15-minute interval and cross-referenced to the gage-height measurement recorded at the spillway streamgage (Fena Dam Spillway near Agat, Guam, station 16849000; fig. 1). The vertical datum of the streamgage is referenced to the spillway such that a gage height of $0.0 \mathrm{ft}$ corresponds to the spillway crest. The corresponding bed elevation, in $\mathrm{ft} \mathrm{GUVD04,} \mathrm{for}$ each depth sounding was then calculated using equation 1 :

$$
E=S+110.8 f t-D
$$

where
$E \quad$ is bed elevation, in $\mathrm{ft} \mathrm{GUVD04;}$
$S$ is gage height recorded at the spillway, in $\mathrm{ft}$; and
$D \quad$ is depth of sounding, in $\mathrm{ft}$. 

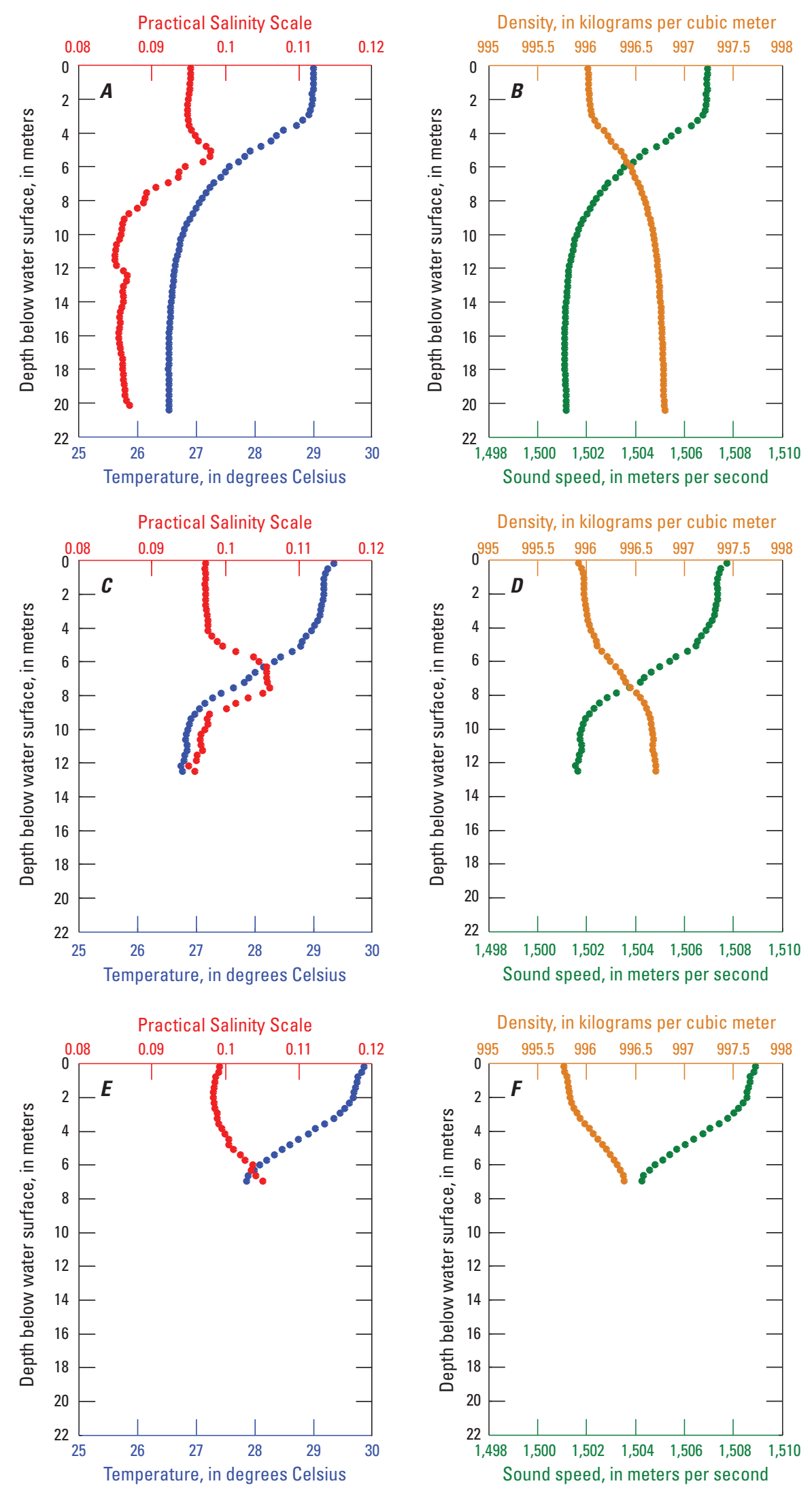

Figure 7. Examples of water temperature, salinity, density, and sound-speed profiles at three locations within the reservoir: $A$ and $B$, cast from the downstream part of the reservoir near the dam (depth, 20.4 meters, 66.9 feet); $C$ and $D$, cast from the middle part of the reservoir (depth, 12.5 meters, 41.0 feet); and $E$ and $F$, cast from the upstream part of the reservoir (depth, 7.0 meters, 23 feet). Salinity is shown using the practical salinity scale (PSS-78). On plots A, C, and E, blue points indicate temperature and red points indicate salinity. On plots $B, D$, and $F$, green points indicate velocity and brown points indicate density. 


\section{Digital Elevation Model Development}

The bed elevation and additional topographic survey points in the Imong River and delta were merged and imported into $\operatorname{ArcGIS}^{\text {TM }}$ (ESRI Inc., 2013) as a shapefile. Erroneous bedelevation points, likely caused by sound-wave reflections from the CastAway ${ }^{\mathrm{TM}} \mathrm{CTD}$, were removed from the dataset. A digital elevation model (DEM) was created in ArcGIS by using a nearest-neighbor interpolation algorithm. The elevation data from the DEM were then exported and tabulated in MATLAB $^{\circledR}$ (The MathWorks Inc., 2014) to obtain the surface area and cumulative storage volume at 0.1 -foot stage intervals. The bathymetric raster dataset was also used to generate contours at 5-foot intervals using an algorithm in ArcGIS. The contours were created only for the figure and were not used to calculate storage capacity. Contours smaller than about $50 \mathrm{ft}$ are not shown.

The transducers in the Sontek M9 ADCP were calibrated by the manufacturer, and no calibration adjustments by the operator were needed. As an indirect check that the ADCP was functioning properly, we compared the maximum depth recorded in each CTD cast (referred to as "CTD-measured depth") to the depth derived from the DEM (referred to as "DEM-derived depth") at that location. Several of the casts collected had high horizontal-positioning error (greater than about $10 \mathrm{ft}$ ). This amount of error is acceptable for largescale adjustments of sound-speed corrections but not for comparisons to DEM-derived depths; therefore, casts with large horizontal error were not used in the comparison. Also, several of the casts were collected in areas with steep bed topography; in those areas if the boat drifted a few meters from the GPS-derived location of the cast while the CastAwayCTD was still underwater, the CTD-measured depth could differ significantly from the DEM-derived depth. Excluding the casts collected in areas with mildly sloped to steep bed topography, the average depth of the remaining casts was $35.08 \mathrm{ft}$ with a range of 3.93-67.06 ft. On average, the CTD-measured depth was $0.40 \mathrm{ft}$ deeper than the DEM-derived depth. Differences in depth could be due to instrumentation error, interpolation between depth soundings, or possibly from the CastAway CTD penetrating the soft bed material in the upper layers of sediment. In general, excluding the casts collected in areas with mildly sloped to steep bed topography, the DEM-derived depths and CTD-measured depths corresponded well. In addition to performing daily system checks on the ADCP, this indirect check against the CTD-measured depths provided additional assurance that the Sontek M9 ADCP was functioning properly.

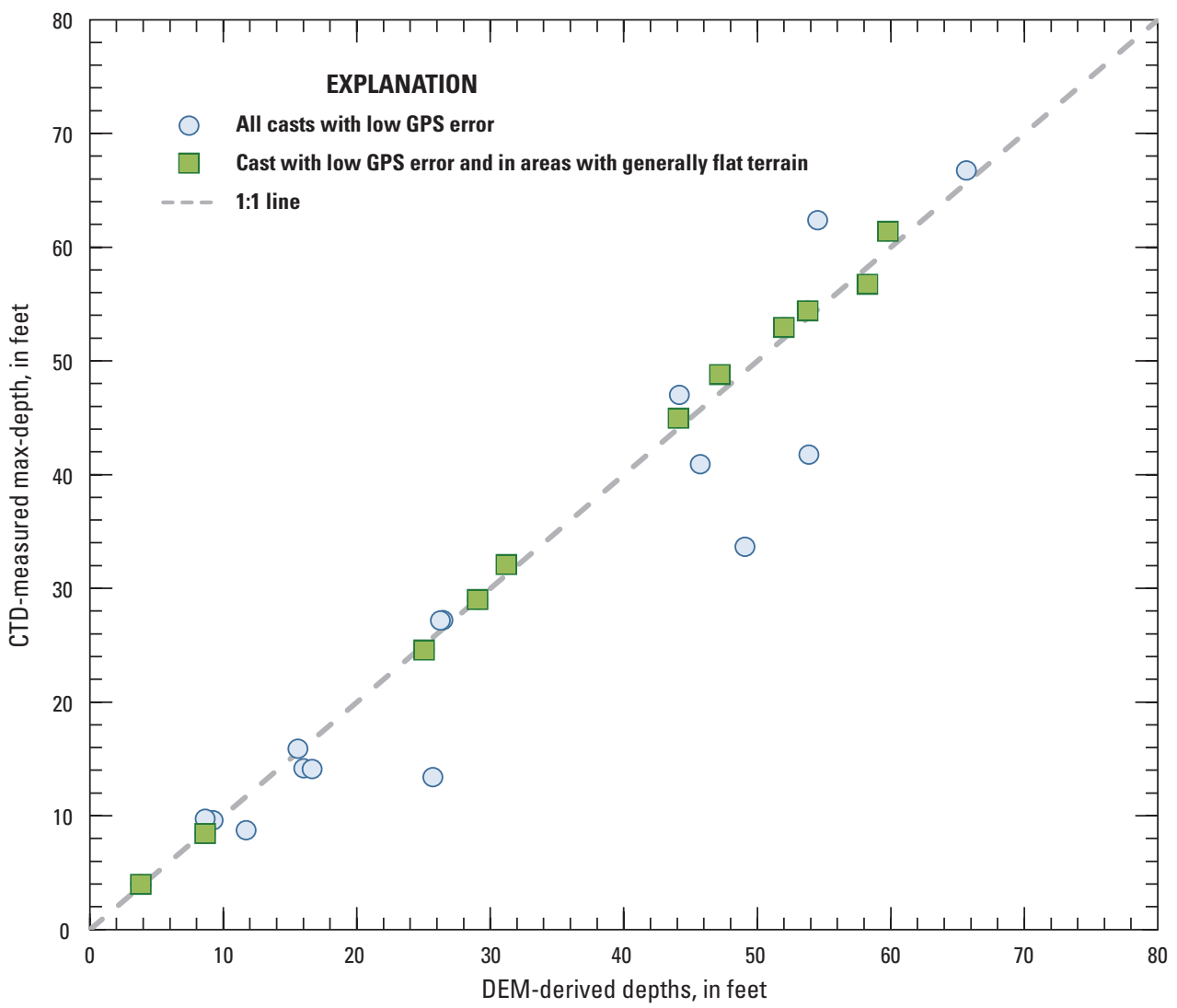

Figure 8. Maximum depths measured using the CastAway Conductivity, Temperature, and Depth profiler in relation to depths derived from the digital elevation model of the Fena Valley Reservoir, Guam, 2014. Casts with Global Positioning System (GPS) error greater than 10 feet were not included in this comparison. Depths from casts collected in areas with generally flat terrain, which would provide a better check against the digital elevation model (DEM)-derived depths, are shown by dark-green markers. (CTD, CastAway Conductivity, Temperature, and Depth). 


\section{Results}

In this section the results of the 2014 Fena Valley

Reservoir capacity analysis are compared to the initial capacity. The 1951 stage-area and stage-capacity curves were digitized from the engineering drawings of record (Frederic R. Harris, Inc., 1949) by using PlotDigitizer software (Huwaldt and Steinhorst, 2012).

\section{Bathymetry}

Results of the 2014 bathymetric survey of the reservoir are shown in figure 9 . Approximately 380,000 depth soundings and about 2,100 topographic points were used to create the bathymetric map with a point density generally ranging from 0.02 to 0.21 points per $\mathrm{ft}^{2}$ (average about 1 point per $22 \mathrm{ft}^{2}$ ).

The bathymetric map shows that remnants of the Fena River channel are still fairly well defined in the northern two-thirds of the reservoir. However, significant sediment deposition has occurred in the southern part of the reservoir, particularly just downstream from the Imong and Almagosa Rivers, to the degree that sediment has completely buried the river channels in this area of the reservoir. Coarse sediment (cobbles, sand, and silt) typically settles out quickly near river mouths in a reservoir. In the Fena Valley Reservoir, the Imong River has the most pronounced deltaic deposits. The Almagosa River also contributes a large amount of sediment; however, there was very little noticeable sediment accumulation near the Maulap River mouth. On the basis of this evidence, the Imong River watershed probably contributes the greatest volume of sediment to the reservoir.

In the other parts of the reservoir, if sediment deposition has occurred, it is more uniformly distributed such that some detail of the underlying topography (prior to reservoir inundation) is visible in the bathymetric map. For example, in addition to the visible former Fena River channel, remnants of the retaining levees used during construction of the Fena Dam are also visible in the bathymetric map. These levees are in the downstream-most part of the reservoir, starting diagonally just south of the boat launch area, then following the northern bank of the former Fena River to the screen house.

\section{Reservoir Storage Capacity}

The total storage capacity of the Fena Valley Reservoir determined from the 2014 bathymetric survey was 6,915 acre-ft. Rating tables for the surface area and reservoir volume at 0.1 -foot stage intervals are provided in tables 3 and 4. The reservoir volume is shown as a stage-capacity curve, along with the 1951 stage-capacity curve, in figure 10.

The total reservoir storage capacity has decreased from 8,365 acre-ft in 1951 to 6,915 acre-ft in 2014 (a loss of 17 percent). The live storage capacity has decreased from 5,883 acre-ft in 1951 to 5,511 acre-ft in 2014 (a loss of 6 percent), and the dead storage capacity has decreased from 2,482 acre-ft in 1951 to 1,404 acre-ft in 2014 (a loss of 43 percent). Seventy-five percent of the capacity loss was in the dead storage. The dead-storage area (defined as the reservoir bed which lies below the lowest-level outlet elevation) extends south from the dam to about the location of the former (that is submerged) confluence of the Almagosa River and the Fena River. On the basis of the historical rates of deposition, a greater portion of future sediment may still end up in the dead storage area; however, sedimentation in the live storage area (or usable storage) is likely to continue, which will affect reservoir management.

At this time we cannot estimate rates of sedimentation because of the uncertainty in the methods used during previous surveys, as well as unknowns regarding the watershed response to infrequent, but major, storms, which could deliver large volumes of sediment. Further analysis is needed to quantify the error associated with the previous surveys and then place those results in the context of the hydrologic history of the watershed. 


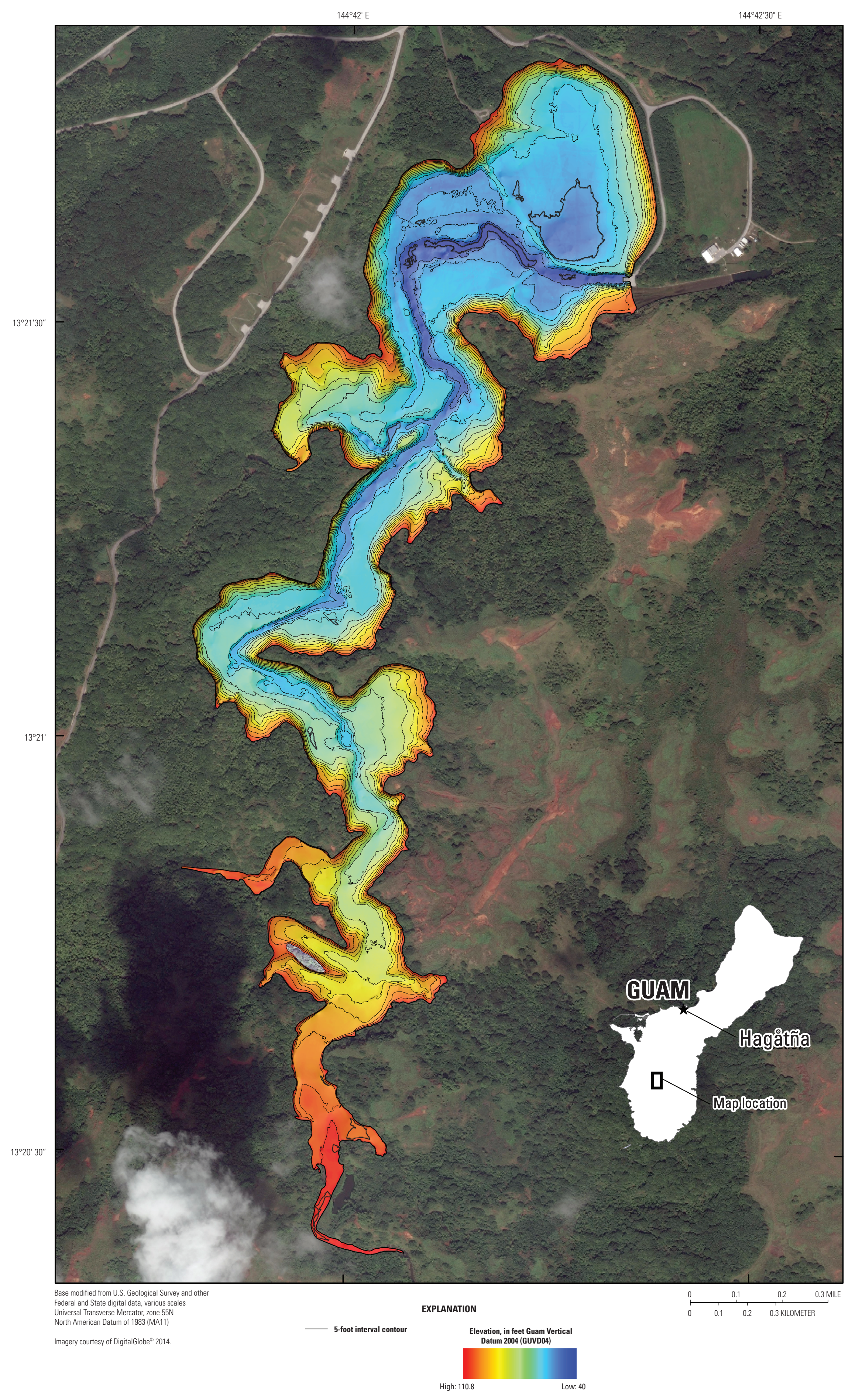

Figure 9. Bathymetry and 5-foot interval contours, based on the February 2014 survey, Fena Valley Reservoir, Guam. 
16 Storage Capacity of the Fena Valley Reservoir, Guam, Mariana Islands, 2014

Table 3. Rating table for surface area of the Fena Valley Reservoir, Guam, 2014.

\begin{tabular}{|c|c|c|c|c|c|c|c|c|c|c|}
\hline \multirow{2}{*}{ 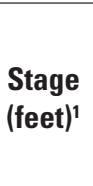 } & \multicolumn{10}{|c|}{$\begin{array}{l}\text { Surface area } \\
\text { (acres) }\end{array}$} \\
\hline & \multicolumn{10}{|c|}{ Intervals } \\
\hline 42 & 0 & 0 & 0 & 0 & 0 & 0 & 0 & 0.1 & 0.2 & 0.2 \\
\hline 43 & 0.3 & 0.3 & 0.3 & 0.4 & 0.4 & 0.4 & 0.5 & 0.5 & 0.6 & 0.6 \\
\hline 46 & 2.3 & 2.4 & 2.5 & 2.7 & 2.8 & 2.9 & 3.0 & 3.1 & 3.2 & 3.3 \\
\hline 47 & 3.4 & 3.5 & 3.6 & 3.7 & 3.8 & 3.8 & 3.9 & 4.0 & 4.1 & 4.2 \\
\hline 48 & 4.2 & 4.3 & 4.4 & 4.5 & 4.6 & 4.6 & 4.7 & 4.8 & 4.9 & 5.0 \\
\hline 49 & 5.0 & 5.1 & 5.2 & 5.3 & 5.4 & 5.4 & 5.5 & 5.6 & 5.7 & 5.8 \\
\hline 53 & 13.7 & 14.1 & 14.5 & 15.0 & 15.4 & 15.9 & 16.3 & 16.8 & 17.2 & 17.7 \\
\hline 54 & 18.2 & 18.6 & 19.1 & 19.5 & 20.0 & 20.5 & 21.0 & 21.5 & 22.1 & 22.6 \\
\hline 55 & 23.1 & 23.7 & 24.3 & 24.8 & 25.4 & 26.0 & 26.7 & 27.2 & 27.8 & 28.4 \\
\hline 56 & 28.9 & 29.5 & 30.0 & 30.6 & 31.2 & 31.7 & 32.3 & 32.8 & 33.4 & 33.9 \\
\hline 57 & 34.5 & 35.1 & 35.7 & 36.3 & 36.9 & 37.6 & 38.2 & 38.8 & 39.4 & 40.1 \\
\hline 58 & 40.8 & 41.5 & 42.1 & 42.8 & 43.4 & 44.1 & 44.8 & 45.4 & 46.0 & 46.7 \\
\hline 59 & 47.3 & 47.9 & 48.6 & 49.2 & 49.8 & 50.4 & 50.9 & 51.5 & 52.0 & 52.6 \\
\hline 60 & 53.1 & 53.5 & 54.0 & 54.5 & 55.0 & 55.5 & 55.9 & 56.4 & 56.8 & 57.3 \\
\hline 61 & 57.7 & 58.1 & 58.5 & 59.0 & 59.4 & 59.8 & 60.2 & 60.6 & 61.1 & 61.5 \\
\hline 67 & 83.6 & 84.0 & 84.3 & 84.7 & 85.1 & 85.5 & 85.8 & 86.2 & 86.5 & 86.9 \\
\hline 68 & 87.2 & 87.6 & 88.0 & 88.3 & 88.7 & 89.1 & 89.4 & 89.7 & 90.1 & 90.4 \\
\hline 69 & 90.7 & 91.0 & 91.4 & 91.7 & 92.0 & 92.3 & 92.6 & 92.9 & 93.1 & 93.4 \\
\hline 70 & 93.7 & 94.0 & 94.3 & 94.5 & 94.8 & 95.1 & 95.4 & 95.6 & 95.9 & 96.2 \\
\hline 71 & 96.5 & 96.8 & 97.1 & 97.4 & 97.7 & 98.0 & 98.3 & 98.6 & 99.0 & 99.3 \\
\hline 72 & 99.6 & 100.0 & 100.3 & 100.6 & 100.9 & 101.2 & 101.5 & 101.8 & 102.0 & 102.3 \\
\hline 73 & 102.6 & 102.8 & 103.1 & 103.3 & 103.6 & 103.8 & 104.1 & 104.3 & 104.6 & 104.8 \\
\hline 74 & 105.1 & 105.4 & 105.7 & 106.0 & 106.2 & 106.5 & 106.8 & 107.1 & 107.3 & 107.6 \\
\hline 75 & 107.8 & 108.1 & 108.3 & 108.6 & 108.8 & 109.1 & 109.3 & 109.6 & 109.8 & 110.1 \\
\hline 76 & 110.3 & 110.6 & 110.8 & 111.1 & 111.3 & 111.6 & 111.8 & 112.1 & 112.3 & 112.6 \\
\hline 77 & 112.8 & 113.1 & 113.4 & 113.6 & 113.9 & 114.1 & 114.4 & 114.6 & 114.9 & 115.1 \\
\hline
\end{tabular}


Table 3. Rating table for surface area of the Fena Valley Reservoir, Guam, 2014. - Continued

\begin{tabular}{|c|c|c|c|c|c|c|c|c|c|c|}
\hline \multirow{3}{*}{$\begin{array}{l}\text { Stage } \\
\text { (feet) }\end{array}$} & \multicolumn{10}{|c|}{$\begin{array}{l}\text { Surface area } \\
\text { (acres) }\end{array}$} \\
\hline & \multicolumn{10}{|c|}{ Intervals } \\
\hline & 0.0 & 0.1 & 0.2 & 0.3 & 0.4 & 0.5 & 0.6 & 0.7 & 0.8 & 0.9 \\
\hline 78 & 115.4 & 115.6 & 115.9 & 116.1 & 116.4 & 116.6 & 116.9 & 117.2 & 117.4 & 117.7 \\
\hline 79 & 117.9 & 118.2 & 118.4 & 118.7 & 118.9 & 119.2 & 119.4 & 119.7 & 119.9 & 120.2 \\
\hline 80 & 120.4 & 120.6 & 120.9 & 121.1 & 121.3 & 121.6 & 121.8 & 122.0 & 122.3 & 122.5 \\
\hline 81 & 122.8 & 123.0 & 123.3 & 123.6 & 123.8 & 124.1 & 124.3 & 124.6 & 124.9 & 125.1 \\
\hline 82 & 125.4 & 125.7 & 125.9 & 126.2 & 126.4 & 126.6 & 126.9 & 127.1 & 127.3 & 127.5 \\
\hline 83 & 127.8 & 128.0 & 128.2 & 128.4 & 128.6 & 128.8 & 129.1 & 129.3 & 129.5 & 129.7 \\
\hline 84 & 130.0 & 130.2 & 130.4 & 130.6 & 130.8 & 131.1 & 131.3 & 131.5 & 131.7 & 131.9 \\
\hline 85 & 132.1 & 132.3 & 132.5 & 132.7 & 132.9 & 133.1 & 133.3 & 133.5 & 133.7 & 134.0 \\
\hline 86 & 134.2 & 134.4 & 134.6 & 134.8 & 135.0 & 135.2 & 135.4 & 135.7 & 135.9 & 136.1 \\
\hline 87 & 136.3 & 136.5 & 136.7 & 136.9 & 137.1 & 137.4 & 137.6 & 137.8 & 138.0 & 138.3 \\
\hline 88 & 138.5 & 138.7 & 139.0 & 139.2 & 139.4 & 139.7 & 139.9 & 140.1 & 140.4 & 140.6 \\
\hline 89 & 140.9 & 141.1 & 141.3 & 141.5 & 141.8 & 142.0 & 142.2 & 142.4 & 142.7 & 142.9 \\
\hline 90 & 143.1 & 143.3 & 143.5 & 143.8 & 144.0 & 144.2 & 144.4 & 144.6 & 144.8 & 145.1 \\
\hline 91 & 145.3 & 145.5 & 145.7 & 145.9 & 146.1 & 146.4 & 146.6 & 146.8 & 147.1 & 147.3 \\
\hline 92 & 147.5 & 147.7 & 148.0 & 148.2 & 148.4 & 148.7 & 148.9 & 149.1 & 149.4 & 149.6 \\
\hline 93 & 149.8 & 150.1 & 150.3 & 150.6 & 150.8 & 151.0 & 151.3 & 151.5 & 151.8 & 152.1 \\
\hline 94 & 152.3 & 152.6 & 152.8 & 153.1 & 153.3 & 153.6 & 153.9 & 154.1 & 154.4 & 154.6 \\
\hline 95 & 154.9 & 155.2 & 155.4 & 155.7 & 155.9 & 156.2 & 156.4 & 156.7 & 157.0 & 157.2 \\
\hline 96 & 157.5 & 157.8 & 158.0 & 158.3 & 158.6 & 158.8 & 159.1 & 159.4 & 159.6 & 159.9 \\
\hline 97 & 160.2 & 160.4 & 160.7 & 161.0 & 161.2 & 161.5 & 161.8 & 162.0 & 162.2 & 162.5 \\
\hline 98 & 162.7 & 163.0 & 163.2 & 163.5 & 163.7 & 164.0 & 164.2 & 164.4 & 164.7 & 164.9 \\
\hline 99 & 165.1 & 165.3 & 165.6 & 165.8 & 166.0 & 166.3 & 166.5 & 166.7 & 166.9 & 167.2 \\
\hline 100 & 167.4 & 167.7 & 167.9 & 168.1 & 168.3 & 168.5 & 168.8 & 169.0 & 169.2 & 169.5 \\
\hline 101 & 169.7 & 170.0 & 170.2 & 170.4 & 170.7 & 170.9 & 171.2 & 171.4 & 171.7 & 171.9 \\
\hline 102 & 172.1 & 172.3 & 172.6 & 172.8 & 173.0 & 173.2 & 173.4 & 173.7 & 173.9 & 174.2 \\
\hline 103 & 174.4 & 174.6 & 174.8 & 175.0 & 175.2 & 175.4 & 175.7 & 175.9 & 176.1 & 176.4 \\
\hline 104 & 176.6 & 176.8 & 177.1 & 177.3 & 177.5 & 177.7 & 178.0 & 178.2 & 178.4 & 178.6 \\
\hline 105 & 178.8 & 179.1 & 179.3 & 179.5 & 179.7 & 180.0 & 180.2 & 180.4 & 180.6 & 180.8 \\
\hline 106 & 181.0 & 181.3 & 181.5 & 181.7 & 182.0 & 182.2 & 182.5 & 182.7 & 182.9 & 183.2 \\
\hline 107 & 183.4 & 183.6 & 183.7 & 184.0 & 184.2 & 184.4 & 184.6 & 184.8 & 184.9 & 185.1 \\
\hline 108 & 185.3 & 185.5 & 185.7 & 185.9 & 186.0 & 186.2 & 186.4 & 186.6 & 186.7 & 186.9 \\
\hline 109 & 187.0 & 187.2 & 187.4 & 187.6 & 187.7 & 187.9 & 188.1 & 188.3 & 188.5 & 188.7 \\
\hline 110 & 189.0 & 189.4 & 189.8 & 190.2 & 190.6 & 190.9 & 191.2 & 191.5 & 192.6 & \\
\hline
\end{tabular}

${ }^{1}$ Elevation in feet referenced to Guam Vertical Datum of 2004 (GUVD04). 
18 Storage Capacity of the Fena Valley Reservoir, Guam, Mariana Islands, 2014

Table 4. Rating table for storage capacity of the Fena Valley Reservoir, Guam, 2014.

\begin{tabular}{|c|c|c|c|c|c|c|c|c|c|c|}
\hline \multirow{2}{*}{ 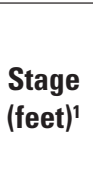 } & \multicolumn{10}{|c|}{$\begin{array}{c}\text { Storage capacity } \\
\text { (acre-feet) }\end{array}$} \\
\hline & \multicolumn{10}{|c|}{ Intervals } \\
\hline 42 & 0 & 0 & 0 & 0 & 0 & 0 & 0 & 0.1 & 0.1 & 0.1 \\
\hline 43 & 0.1 & 0.1 & 0.2 & 0.2 & 0.3 & 0.3 & 0.3 & 0.4 & 0.5 & 0.5 \\
\hline 46 & 3.3 & 3.5 & 3.8 & 4.0 & 4.3 & 4.6 & 4.9 & 5.2 & 5.5 & 5.9 \\
\hline 47 & 6.2 & 6.5 & 6.9 & 7.3 & 7.6 & 8.0 & 8.4 & 8.8 & 9.2 & 9.7 \\
\hline 48 & 10.1 & 10.5 & 10.9 & 11.4 & 11.9 & 12.3 & 12.8 & 13.3 & 13.8 & 14.3 \\
\hline 49 & 14.8 & 15.3 & 15.8 & 16.3 & 16.8 & 17.4 & 17.9 & 18.5 & 19.1 & 19.7 \\
\hline 53 & 47.6 & 49.0 & 50.5 & 52.0 & 53.5 & 55.1 & 56.8 & 58.4 & 60.2 & 61.9 \\
\hline 54 & 63.7 & 65.6 & 67.5 & 69.5 & 71.5 & 73.5 & 75.6 & 77.8 & 80.0 & 82.2 \\
\hline 55 & 84.6 & 86.9 & 89.4 & 91.8 & 94.4 & 97.0 & 100 & 102 & 105 & 108 \\
\hline 56 & 111 & 114 & 117 & 120 & 123 & 126 & 129 & 133 & 136 & 139 \\
\hline 57 & 143 & 146 & 150 & 154 & 157 & 161 & 165 & 169 & 173 & 177 \\
\hline 58 & 181 & 185 & 189 & 193 & 198 & 202 & 207 & 211 & 216 & 220 \\
\hline 59 & 225 & 230 & 235 & 240 & 245 & 250 & 255 & 260 & 265 & 270 \\
\hline 60 & 276 & 281 & 287 & 292 & 297 & 303 & 309 & 314 & 320 & 326 \\
\hline 61 & 331 & 337 & 343 & 349 & 355 & 361 & 367 & 373 & 379 & 385 \\
\hline 67 & 759 & 767 & 776 & 784 & 793 & 801 & 810 & 818 & 827 & 836 \\
\hline 68 & 844 & 853 & 862 & 871 & 880 & 889 & 898 & 907 & 916 & 925 \\
\hline 69 & 934 & 943 & 952 & 961 & 970 & 979 & 989 & 998 & 1,007 & 1,017 \\
\hline 70 & 1,026 & 1,035 & 1,045 & 1,054 & 1,064 & 1,073 & 1,083 & 1,092 & 1,102 & 1,112 \\
\hline 71 & 1,121 & 1,131 & 1,141 & 1,150 & 1,160 & 1,170 & 1,180 & 1,190 & 1,200 & 1,209 \\
\hline 72 & 1,219 & 1,229 & 1,239 & 1,250 & 1,260 & 1,270 & 1,280 & 1,290 & 1,300 & 1,311 \\
\hline 73 & 1,321 & 1,331 & 1,341 & 1,352 & 1,362 & 1,372 & 1,383 & 1,393 & 1,404 & 1,414 \\
\hline 74 & 1,425 & 1,435 & 1,446 & 1,456 & 1,467 & 1,478 & 1,488 & 1,499 & 1,510 & 1,521 \\
\hline 75 & 1,531 & 1,542 & 1,553 & 1,564 & 1,575 & 1,586 & 1,597 & 1,608 & 1,619 & 1,630 \\
\hline 76 & 1,641 & 1,652 & 1,663 & 1,674 & 1,685 & 1,696 & 1,707 & 1,718 & 1,730 & 1,741 \\
\hline 77 & 1,752 & 1,764 & 1,775 & 1,786 & 1,798 & 1,809 & 1,820 & 1,832 & 1,843 & 1,855 \\
\hline
\end{tabular}


Table 4. Rating table for storage capacity of the Fena Valley Reservoir, Guam, 2014.-Continued

\begin{tabular}{|c|c|c|c|c|c|c|c|c|c|c|}
\hline \multirow{3}{*}{$\begin{array}{l}\text { Stage } \\
\text { (feet) })^{1}\end{array}$} & \multicolumn{10}{|c|}{$\begin{array}{c}\text { Storage capacity } \\
\text { (acre-feet) }\end{array}$} \\
\hline & \multicolumn{10}{|c|}{ Intervals } \\
\hline & 0.0 & 0.1 & 0.2 & 0.3 & 0.4 & 0.5 & 0.6 & 0.7 & 0.8 & 0.9 \\
\hline 78 & 1,866 & 1,878 & 1,890 & 1,901 & 1,913 & 1,925 & 1,936 & 1,948 & 1,960 & 1,971 \\
\hline 79 & 1,983 & 1,995 & 2,007 & 2,019 & 2,031 & 2,043 & 2,055 & 2,067 & 2,078 & 2,091 \\
\hline 80 & 2,103 & 2,115 & 2,127 & 2,139 & 2,151 & 2,163 & 2,175 & 2,187 & 2,200 & 2,212 \\
\hline 81 & 2,224 & 2,237 & 2,249 & 2,261 & 2,274 & 2,286 & 2,298 & 2,311 & 2,323 & 2,336 \\
\hline 82 & 2,348 & 2,361 & 2,374 & 2,386 & 2,399 & 2,412 & 2,424 & 2,437 & 2,450 & 2,462 \\
\hline 83 & 2,475 & 2,488 & 2,501 & 2,514 & 2,527 & 2,539 & 2,552 & 2,565 & 2,578 & 2,591 \\
\hline 84 & 2,604 & 2,617 & 2,630 & 2,643 & 2,656 & 2,669 & 2,683 & 2,696 & 2,709 & 2,722 \\
\hline 85 & 2,735 & 2,749 & 2,762 & 2,775 & 2,788 & 2,802 & 2,815 & 2,828 & 2,842 & 2,855 \\
\hline 86 & 2,869 & 2,882 & 2,895 & 2,909 & 2,922 & 2,936 & 2,949 & 2,963 & 2,977 & 2,990 \\
\hline 87 & 3,004 & 3,018 & 3,031 & 3,045 & 3,059 & 3,072 & 3,086 & 3,100 & 3,114 & 3,128 \\
\hline 88 & 3,141 & 3,155 & 3,169 & 3,183 & 3,197 & 3,211 & 3,225 & 3,239 & 3,253 & 3,267 \\
\hline 89 & 3,281 & 3,295 & 3,309 & 3,324 & 3,338 & 3,352 & 3,366 & 3,380 & 3,395 & 3,409 \\
\hline 90 & 3,423 & 3,438 & 3,452 & 3,466 & 3,481 & 3,495 & 3,510 & 3,524 & 3,539 & 3,553 \\
\hline 91 & 3,568 & 3,582 & 3,597 & 3,611 & 3,626 & 3,641 & 3,655 & 3,670 & 3,685 & 3,699 \\
\hline 92 & 3,714 & 3,729 & 3,744 & 3,758 & 3,773 & 3,788 & 3,803 & 3,818 & 3,833 & 3,848 \\
\hline 93 & 3,863 & 3,878 & 3,893 & 3,908 & 3,923 & 3,938 & 3,953 & 3,968 & 3,984 & 3,999 \\
\hline 94 & 4,014 & 4,029 & 4,045 & 4,060 & 4,075 & 4,091 & 4,106 & 4,121 & 4,137 & 4,152 \\
\hline 95 & 4,168 & 4,183 & 4,199 & 4,214 & 4,230 & 4,246 & 4,261 & 4,277 & 4,293 & 4,308 \\
\hline 96 & 4,324 & 4,340 & 4,356 & 4,371 & 4,387 & 4,403 & 4,419 & 4,435 & 4,451 & 4,467 \\
\hline 97 & 4,483 & 4,499 & 4,515 & 4,531 & 4,547 & 4,564 & 4,580 & 4,596 & 4,612 & 4,628 \\
\hline 98 & 4,645 & 4,661 & 4,677 & 4,694 & 4,710 & 4,726 & 4,743 & 4,759 & 4,776 & 4,792 \\
\hline 99 & 4,809 & 4,825 & 4,842 & 4,858 & 4,875 & 4,892 & 4,908 & 4,925 & 4,942 & 4,958 \\
\hline 100 & 4,975 & 4,992 & 5,009 & 5,025 & 5,042 & 5,059 & 5,076 & 5,093 & 5,110 & 5,127 \\
\hline 101 & 5,144 & 5,161 & 5,178 & 5,195 & 5,212 & 5,229 & 5,246 & 5,263 & 5,280 & 5,298 \\
\hline 102 & 5,315 & 5,332 & 5,349 & 5,367 & 5,384 & 5,401 & 5,419 & 5,436 & 5,453 & 5,471 \\
\hline 103 & 5,488 & 5,506 & 5,523 & 5,541 & 5,558 & 5,576 & 5,593 & 5,611 & 5,628 & 5,646 \\
\hline 104 & 5,664 & 5,681 & 5,699 & 5,717 & 5,735 & 5,752 & 5,770 & 5,788 & 5,806 & 5,824 \\
\hline 105 & 5,842 & 5,860 & 5,877 & 5,895 & 5,913 & 5,931 & 5,949 & 5,967 & 5,985 & 6,004 \\
\hline 106 & 6,022 & 6,040 & 6,058 & 6,076 & 6,094 & 6,113 & 6,131 & 6,149 & 6,167 & 6,186 \\
\hline 107 & 6,204 & 6,222 & 6,241 & 6,259 & 6,278 & 6,296 & 6,314 & 6,333 & 6,351 & 6,370 \\
\hline 108 & 6,388 & 6,407 & 6,426 & 6,444 & 6,463 & 6,481 & 6,500 & 6,519 & 6,537 & 6,556 \\
\hline 109 & 6,575 & 6,593 & 6,612 & 6,631 & 6,650 & 6,669 & 6,687 & 6,706 & 6,725 & 6,744 \\
\hline 110 & 6,763 & 6,782 & 6,801 & 6,820 & 6,839 & 6,858 & 6,877 & 6,896 & 6,915 & \\
\hline
\end{tabular}

${ }^{1}$ Elevation in feet referenced to Guam Vertical Datum of 2004 (GUVD04). 
$\boldsymbol{A}$

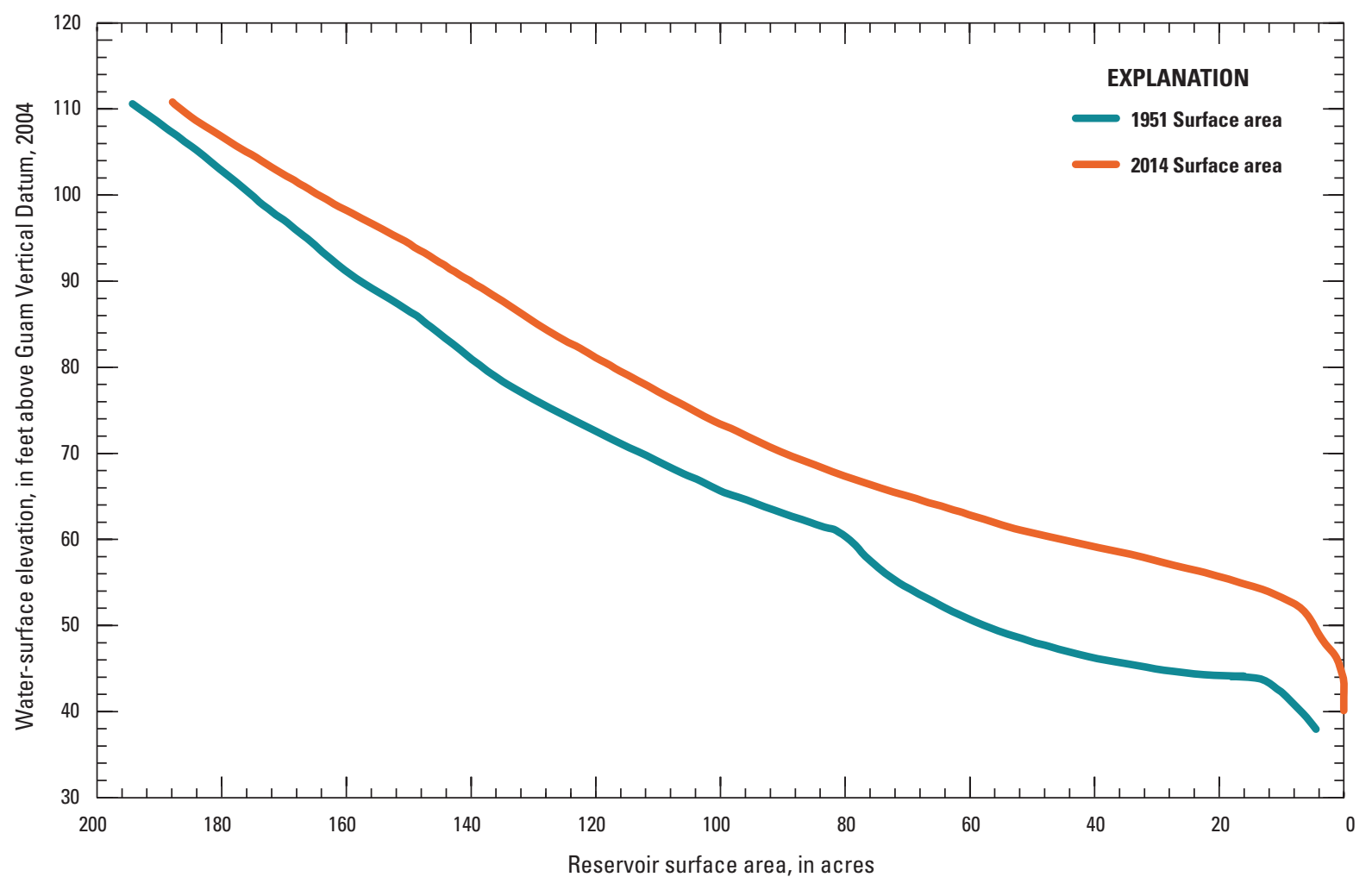

$\boldsymbol{B}$

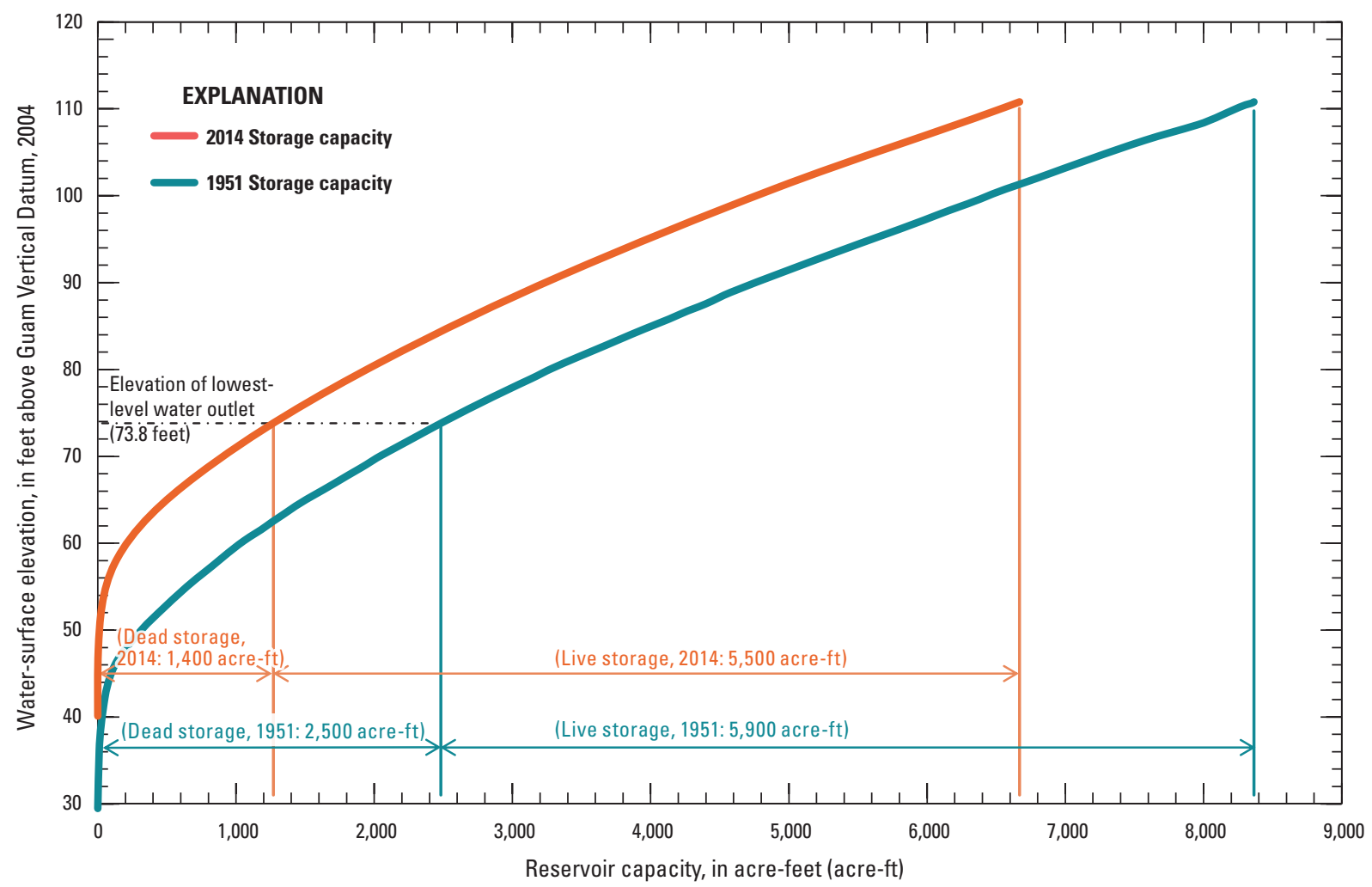

Figure 10. A, stage-surface area curves for 1951 and 2014; and; B, stage-capacity curves with live and dead storage capacity in 1951 and 2014 indicated, Fena Valley Reservoir, Guam. 


\section{Summary}

Since construction of the Fena Dam in 1951, sediment has been accumulating in the Fena Valley Reservoir. The reservoir was surveyed prior to dam construction, as well as in 1973, 1979, and 1990. In order to accurately predict surfacewater availability, up-to-date reservoir capacity information is needed by the U.S. Navy. In response, the U.S. Geological Survey (USGS), in cooperation with the U.S. Department of Defense Strategic Environmental Research and Development Program, surveyed the bathymetry of the reservoir in February 2014 to determine its current storage capacity and to create updated reservoir stage-surface area and stage-capacity curves.

Methods are presented for the collection of data on depth soundings, topographic survey points, and temperature and depth within the water column to correct the depth soundings. Depth soundings and topographic points were then interpolated to create a bathymetric map of the reservoir. During the February 2014 survey, data on approximately 380,000 depth soundings, 2,100 topographic points, and 45 conductivity, temperature, and depth (CTD) profiles were collected. Results from the CTD profiles show that temperature varied slightly, and salinity was relatively constant. The depth soundings were corrected for temperature gradients, merged with topographic survey points in the shallow areas of the Imong River, and spatially interpolated to create a bathymetric map of the reservoir in the form of a digital elevation model (DEM). Elevations from the DEM were tabulated to generate the stage-surface area and stagecapacity tables presented in this report.

A control survey was conducted using Global Navigation Satellite System-Real-Time Kinematic receiver to check the elevations of the spillway and benchmark RP21 (which is used routinely for surveying dam settlement) and to establish a temporary benchmark at the boat launch area. The spillway crest elevation was surveyed at 110.8 feet (ft) Guam Vertical Datum of 2004 (GUVD04), and RP21 was surveyed at $125.41 \mathrm{ft}$. The survey measurements for the spillway-crest elevation and benchmark RP21 were lower than previously published by 0.42 and $0.57 \mathrm{ft}$, respectively. Survey measurements were checked against two additional benchmarks (GGN 2053 and GGN 2054) outside the Naval Base Guam Ordnance Annex near the entrance gate. The measurements made during this study were within $0.1 \mathrm{ft}$ of the known elevation of those two benchmarks. We concluded that the original 1948 measurement of the spillway crest which used the Mean Lower Low Water (MLLW) as the datum was in error and that error has propagated through subsequent studies and local surveys. However, this does not affect the result of those previous surveys since they were surveyed relative to the spillway crest.

Results of the analysis of the bathymetric data indicate that the reservoir currently has a total storage capacity of 6,915 acre-feet (acre-ft). The live-storage capacity was calculated as 5,511 acre-ft. Total reservoir capacity in 1951 was estimated to be 8,365 acre-ft, and the live-storage capacity was estimated to be 5,900 acre-ft. Thus, between 1951 and 2014 , the total storage capacity decreased by 1,449 acre-ft, and the live-storage capacity decreased by 372 acre- $\mathrm{ft}$ (representing losses of 17 and 6 percent of the original capacity, respectively). Between 1951 and 2014, the deadstorage capacity decreased by 1,078 acre-ft, which represents a loss of 43 percent of the original 2,482 acre-ft dead-storage capacity.

Although the overall reservoir capacity is continuing to decline, most of the sediment accumulation has occurred in the dead-storage area of the reservoir. On the basis of the historical rates of deposition, a greater portion of future sediment may still end up in the dead storage area; however, sedimentation in the live storage area (or usable storage) is likely to continue, which will affect reservoir management. Coarse sediment (cobbles, sand, and silt) typically settles out quickly near river mouths in a reservoir. In the Fena Valley Reservoir, the Imong River has the most pronounced deltaic deposits. The Almagosa River also contributes a large amount of sediment; however, there was little noticeable sediment accumulation near the Maulap River mouth. On the basis of this evidence, the Imong River watershed is probably the primary contributor of sediment to the reservoir. Over the lifetime of the reservoir, the average annual decrease in total reservoir capacity was 23.0 acre-feet per year. However, the sediment delivery is likely to happen at an unsteady rate and could be driven by strong tropical storms. At this time, sedimentation rates cannot be estimated because of the uncertainty in previous surveys and unknowns regarding watershed response to infrequent, but major, storms, which could deliver large volumes of sediment. Further analysis is needed to quantify the error associated with the previous surveys and then place those results in the context of the hydrologic history of the watershed. 


\section{Storage Capacity of the Fena Valley Reservoir, Guam, Mariana Islands, 2014}

\section{References Cited}

Carlson, Edward, Doyle, David, and Smith, Dru, 2009, Development of comprehensive geodetic vertical datums for the United States Pacific Territories of American Samoa, Guam, and the Northern Marianas: Surveying and Land Information Science, v. 69, no. 1, p 5-17.

Chen, C.T., and Millero, F.J., 1977, Speed of sound in seawater at high pressures: Journal of the Acoustical Society of America, v. 62, no. 5, p. 1129-1135.

Curtis, W.F., 1984, Sedimentation survey of Fena Reservoir, Guam, Mariana Islands, 1979: U.S. Geological Survey Water-Resources Investigation Report 84-4125, 15 p.

Department of Commerce, 1948, Tidal station report for station at Pier K, Apra Harbor, established March 10, 1948, Electronically archived microfiche pages 100307314 100307315, accessed July 16, 2014, at https://www.ncdc. noaa.gov/EdadsV2/library/WaterLevelMicrofiche.

Digital Globe Inc., 2014, Satellite image collected February 7, 2014, accessed March 26, 2014, at http://www.digitalglobe. $\mathrm{com} /$.

Environmental Systems Research Institute Inc., 2013, ArcGIS version 10.2.0.3348: Redlands, Calif., Environmental Systems Research Institute, Inc.

Frederic R. Harris, Inc., 1949, Impounding reservoir area and volume curves, architecture and engineering drawing 134-2: San Francisco, Calif., Frederic Harris, Inc.

Gill, S.K., and Schultz, J.R., eds., 2001, Tidal datums and their applications: Silver Spring, Md., National Oceanic and Atmospheric Administration Special Publication NOS CO-OPS 1,112 p. with app.

Highland, L.M., and Bobrowsky, Peter, 2008, The landslide handbook-A guide to understanding landslides: U.S. Geological Survey Circular 1325, 129 p.

Huwaldt, J.A., and Steinhorst, Scott, 2012, Plot Digitizer version 2.6.2, accessed May 29, 2013, at http://plotdigitizer. sourceforge.net/.
Kennedy Engineers. Inc., 1973, Fena watershed and reservoir management and study plan-Phase I and II: San Francisco, Calif., Kennedy Engineers, Inc., 139 p.

MathWorks, Inc., 2014, Matlab Version R2014a: Natick, Mass., MathWorks, Inc.

Microsoft Corporation, 2010, Microsoft Excel version 14.0.7140.5002: Redmond, Wash., Microsoft Corporation.

Nakama, L.Y., 1992, Storage capacity of Fena Valley Reservoir, Guam, Mariana Islands, 1990: U.S. Geological Survey Water-Resources Investigation Report 92-4114, $17 \mathrm{p}$.

National Geodetic Survey, 2011, The national adjustment of 2011 project, alignment of passive control with the latest realization of the North American Datum of 1983: NAD 83 (2011/PA11/MA11), accessed May 4, 2014, at http://www. ngs.noaa.gov/web/surveys/NA2011/.

National Geodetic Survey (NGS), 2012, National Geodetic Database, NGS update, September 11, 2012, GEOID12A model released, accessed February 13, 2014, at http://www. ngs.noaa.gov/GEOID/GEOID12A/.

National Oceanic and Atmospheric Administration, 2014, Climatological report (monthly) for the Guam International Airport, accessed August 2014, at http://www.nws.noaa. gov/climate/ getclimate.php?date $=\& w f o=$ guam $\&$ sid $=G U M$ \&pil=CLM\&recent=yes.

Oberg, K.A., Morlock, S.E., and Caldwell, W.S., 2005, Quality-assurance plan for discharge measurements using acoustic Doppler current profilers: U.S. Geological Survey Scientific Investigations Report 2005-5183, 35 p.

Rydlund, P.H., Jr., and Densmore, B.K., 2012, Methods of practice and guidelines for using survey-grade global navigation satellite systems (GNSS) to establish vertical datum in the United States Geological Survey: U.S. Geological Survey Techniques and Methods, book 11, chap. D1, 102 p. with appendixes.

Schumm, S.A., and Harvey, D.A., 2008, Engineering Geomorphology, chap. 18, in Garcia, M.H., ed., Sedimentation Engineering: Processes, Measurements, Modeling, and Practice: American Society of Civil Engineers, Reston Va., 1132 p. 
Shade, P. J., 1983, Reconnaissance study of stream sedimentation, Southern Guam: U.S. Geological Survey Water-Resources Investigations Report 83-4212, 39 p.

Sontek Inc., 2013, HydroSurveyor User Manual Version 2.00, Software Version 1.4, Firmware Version 3.50: San Diego, Calif., Sontek, Inc., 138 p.

Sontek Inc., 2014, Range, velocity, sound speed and Snell's Law: San Diego, Calif., Sontek Technical Note, Sontek, Inc., 4 p.

Tracey, J.I. Jr., Schlanger, S.O., Stark, J.T., Doan, D.B., and May, H.G., 1964, General geology of Guam: U.S. Geological Survey Professional Paper 403-A, 101 p.

Trimble, 2013, Trimble access general survey software, version 2.10, Revision A, February 2013, 517 p., accessed May 11, 2015, at http://apps.trimbleaccess.com/help/en/ TrimbleAccess $=2013.00$.

Trimble, 2014, Trimble business center software, version 3.40: Trimble Navigation Limited.

United National Educational, Scientific and Cultural Organization (UNESCO), 1981, Background papers and supporting data on the practical salinity scale, 1978: UNESCO Technical Papers.

Ward, P.E., Hoffard, S.H., and Davis, D.A., 1965, Hydrology of Guam: U.S. Geological Survey Professional Paper 403-H, 28 p., 1 pl.

Xylem Inc., 2012a, SonTek HydroSurveyor software and hydrographic surveying ADCP: Xylem, Inc., informational brochure, 2 p., accessed July 9, 2014, at http://www. actonsoftware.com/acton/attachment/1253/ f-00a8/1/-/-/-/-/ HydroSurveyor\%20Brochure\%20\%28Reduced\%29.pdf.

Xylem, Inc., 2012b, CastAway-CTD user's manual 1.5, software version 1.5, firmware version 1.5: San Diego, Calif., Xylem, Inc., 83 p.

Yellow Springs Instruments, 2010, The CastAway CTD brochure with specifications, 2 p., accessed March 11, 2015, at http://www.ysi.com/media/pdfs/E97-CastAway-CTD.pdf. 


\section{Glossary}

Conductivity The raw measurement of specific conductance of water which has not been compensated for temperature.

Dead storage The volume of storage that lies below the lower-level water outlet and therefore cannot be drained through normal dam operations. The dead storage is not usable for water-supply purposes; however, it could be useful for the storage of sediment such that sediment deposition in this region does not decrease the live-storage capacity.

Ellipsoid height The height above or below a mathematically defined surface or ellipsoid that provides a representation of the Earth. The height coordinate determined by a Global Navigation Satellite System (GNSS) observation is related to the surface of the ellipsoid and is then converted to an orthometric height using a geoid model.

Live storage The volume of storage above the lower-level water outlet but below the spillway.

Orthometric height The height of a point on the Earth's surface measured as a distance along a plumb line and normal to gravity from that point to a geoid. 


\section{Appendix. National Geodetic Survey Datasheets}

\section{Benchmark DH3061}

PROGRAM $=$ datasheet95, VERSION $=8.3$

1 National Geodetic Survey, Retrieval Date $=$ FEBRUARY 19, 2014

DH3061

DH3061 DESIGNATION - SABLAN CASTRO

DH3061 PID - DH3061

DH3061 STATE/COUNTY- GU/GUAM

DH3061 COUNTRY - US

DH3061 USGS QUAD - TALOFOFO (1975)

DH3061

DH3061 *CURRENT SURVEY CONTROL

DH3061

DH3061* NAD 83(MA11) POSITION- 1320 21.73008(N) 21513 57.41925(W) ADJUSTED

DH3061* NAD 83(MA11) ELLIP HT- 97.358 (meters) (06/27/12) ADJUSTED

DH3061* NAD 83(MA11) EPOCH - 2010.00

DH3061* GUVD04 ORTHO HEIGHT - 43.884 (meters) 143.98 (feet) ADJUSTED

DH3061

DH3061 NAD 83(MA11) X - -5,070,192.569 (meters) COMP

DH3061 NAD 83(MA11) Y - 3,580,951.707 (meters) COMP

DH3061 NAD 83(MA11) Z - 1,461,985.268 (meters) COMP

DH3061 LAPLACE CORR - $\quad-4.35$ (seconds) DEFLEC12A

DH3061 GEOID HEIGHT - 53.46 (meters) GEOID12A

DH3061 VERT ORDER - FIRST CLASS II

DH3061

DH3061 FGDC Geospatial Positioning Accuracy Standards (95\% confidence, $\mathrm{cm}$ )

DH3061 Type Horiz Ellip Dist(km)

DH3061

$\begin{array}{lll}\text { DH3061 NETWORK } & 4.08 \quad 5.08\end{array}$

DH3061

DH3061 MEDIAN LOCAL ACCURACY AND DIST (014 points) $4.82 \quad 5.08 \quad 12.81$

DH3061

DH3061 NOTE: Click here for information on individual local accuracy

DH3061 values and other accuracy information.

DH3061

DH3061

DH3061.The horizontal coordinates were established by GPS observations

DH3061.and adjusted by the National Geodetic Survey in June 2012.

DH3061

DH3061.NAD 83(MA11) refers to NAD 83 coordinates where the reference

DH3061.frame has been affixed to the stable Mariana tectonic plate.

DH3061

DH3061.The horizontal coordinates are valid at the epoch date displayed above

DH3061.which is a decimal equivalence of Year/Month/Day.

DH3061

DH3061.The orthometric height was determined by differential leveling and

DH3061.adjusted by the NATIONAL GEODETIC SURVEY

DH3061.in May 2005.

DH3061 
DH3061.The X, Y, and Z were computed from the position and the ellipsoidal ht. DH3061

DH3061.The Laplace correction was computed from DEFLEC12A derived deflections. DH3061

DH3061.The ellipsoidal height was determined by GPS observations

DH3061.and is referenced to NAD 83.

DH3061

DH3061. The following values were computed from the NAD 83(MA11) position.

DH3061

DH3061; North East Units Scale Factor Converg.

DH3061;SPC GU $\quad-\quad 182,228.850 \quad 101,883.254$ MT $1.00000004 \quad+00014.4$

DH3061;UTM $55 \quad-1,475,753.271 \quad 258,170.163$ MT $1.00032350 \quad-03055.3$

DH3061

DH3061! - Elev Factor $\mathrm{x}$ Scale Factor $=$ Combined Factor

DH3061!SPC GU $\quad 0.99998469 \times 1.00000004=0.99998473$

DH3061!UTM $55-0.99998469 \times 1.00032350=1.00030818$

DH3061

DH3061 SUPERSEDED SURVEY CONTROL

DH3061

DH3061 NAD 83(1993)- 1320 21.72936(N) 21513 57.41964(W) AD(2004.00) A

DH3061 ELLIP H (06/10/05) 97.315 (m) GP(2004.00) 32

DH3061

DH3061.Superseded values are not recommended for survey control.

DH3061

DH3061.NGS no longer adjusts projects to the NAD 27 or NGVD 29 datums.

DH3061. See file dsdata.txt to determine how the superseded data were derived.

DH3061

DH3061_U.S. NATIONAL GRID SPATIAL ADDRESS: 55PBQ5817075753(NAD 83)

DH3061

DH3061_MARKER: $Z=$ SEE DESCRIPTION

DH3061_SETTING: 7 = SET IN TOP OF CONCRETE MONUMENT

DH3061_MARK LOGO: GUAMLM

DH3061_MAGNETIC: $\mathrm{R}$ = STEEL ROD IMBEDDED IN MONUMENT

DH3061_STABILITY: C = MAY HOLD, BUT OF TYPE COMMONLY SUBJECT TO

DH3061+STABILITY: SURFACE MOTION

DH3061_SATELLITE: THE SITE LOCATION WAS REPORTED AS SUITABLE FOR

DH3061+SATELLITE: SATELLITE OBSERVATIONS - May 21, 2004

DH3061

DH3061 HISTORY - Date Condition Report By

DH3061 HISTORY - 20040521 MONUMENTED GUAMLM

DH3061

DH3061

DH3061

DH3061'DESCRIBED BY GUAM DEPARTMENT OF LAND MANAGEMENT 2004 (TJT)

DH3061'GENERAL STATION LOCATION- THE STATION IS LOCATED IN THE MUNICIPALITY

DH3061'OF TALOFOFO.

DH3061'

DH3061'TO REACH NARRATIVE- TO REACH THE STATION FROM THE JUNCTION OF ROUTE 4

DH3061'AND ROUTE 17, GO SOUTH ON ROUTE 4 FOR 3.5 MILE, STATION ON THE LEFT

DH3061'SIDE OF ROUTE 4 AND 4A. THE STATION IS CENTER WITHIN TALOFOFO BAY

DH3061'OVERLOOK.

DH3061'

DH3061'MONUMENT DESCRIPTION AND MEASUREMENTS- THE STATION IS 13.30M SOUTHEAST

DH3061'FROM A CONCRETE POWER POLE, 23.70M SOUTHEAST FROM CENTERLINE OF ROUTE DH3061'4 AND 5.80M SOUTHWEST FROM THE NORTHEAST CORNER OF A STONE WALL.

DH3061' 
DH3061'THE STATION IS A NO 4 REBAR PROJECTING 1/4 INCH SET IN CONCRETE

DH3061'INSCRIBED DEL. LM 3-24-60 SABLAN CASTRO.

\section{Benchmark DH3040}

PROGRAM $=$ datasheet95, VERSION $=8.3$

1 National Geodetic Survey, Retrieval Date $=$ FEBRUARY 19, 2014

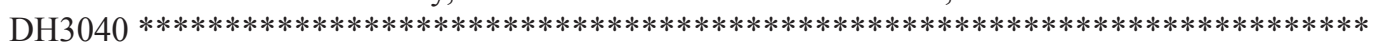

DH3040 DESIGNATION - GGN 2669

DH3040 PID - DH3040

DH3040 STATE/COUNTY- GU/GUAM

DH3040 COUNTRY - US

DH3040 USGS QUAD - TALOFOFO (1975)

DH3040

DH3040 *CURRENT SURVEY CONTROL

DH3040

DH3040* NAD 83(1986) POSITION- $132100 . \quad$ (N) $2151351 . \quad$ (W) SCALED

DH3040* GUVD04 ORTHO HEIGHT - 12.365 (meters) 40.57 (feet) ADJUSTED

DH3040

DH3040 GEOID HEIGHT - 53.53 (meters) GEOID12A

DH3040 VERT ORDER - FIRST CLASS II

DH3040

DH3040.The horizontal coordinates were scaled from a topographic map and have

DH3040.an estimated accuracy of $+/-6$ seconds.

DH3040.

DH3040.The orthometric height was determined by differential leveling and

DH3040.adjusted by the NATIONAL GEODETIC SURVEY

DH3040.in May 2005.

DH3040

DH3040; North East Units Estimated Accuracy

DH3040;SPC GU - 183,410. 102,080. MT (+/- 180 meters Scaled)

DH3040

DH3040 SUPERSEDED SURVEY CONTROL

DH3040

DH3040.No superseded survey control is available for this station.

DH3040

DH3040_U.S. NATIONAL GRID SPATIAL ADDRESS: 55PBQ583769(NAD 83)

DH3040

DH3040_MARKER: DD = SURVEY DISK

DH3040_SETTING: 7 = SET IN TOP OF CONCRETE MONUMENT

DH3040_STAMPING: 2669

DH3040_MARK LOGO: GUAMLM

DH3040_MAGNETIC: $\mathrm{N}=$ NO MAGNETIC MATERIAL

DH3040_STABILITY: C = MAY HOLD, BUT OF TYPE COMMONLY SUBJECT TO

DH3040+STABILITY: SURFACE MOTION

DH3040_SATELLITE: THE SITE LOCATION WAS REPORTED AS SUITABLE FOR

DH3040+SATELLITE: SATELLITE OBSERVATIONS - May 04, 2004

DH3040

DH3040 HISTORY - Date Condition Report By

DH3040 HISTORY - 20040504 MONUMENTED GUAMLM

DH3040

DH3040

STATION DESCRIPTION

DH3040

DH3040’DESCRIBED BY GUAM DEPARTMENT OF LAND MANAGEMENT 2004 (TJT)

DH3040'GENERAL STATION LOCATION- THE STATION IS LOCATED IN SUBURBAN OF IPAN, 
DH3040'THE MUNICIPALITY OF TALOFOFO.

DH3040'

DH3040'TO REACH NARRATIVE- TO REACH THE STATION FROM JUNCTION OF ROUTE 4 AND

DH3040'ROUTE 17, GO SOUTH ON ROUTE 4 FOR 2.5 MILES, TO THE STATION ON THE

DH3040'EAST SIDE OF ROUTE 4 AND ACROSS PAULINO HEIGHTS ROAD. THE MARK IS

DH3040'SOUTH OF BUS SHELTER (YT-95).

DH3040'

DH3040'MONUMENT DESCRIPTION AND MEASUREMENTS- THE STATION IS 8.10M EAST OF

DH3040'CENTERLINE OF ROUTE 4, 12.10M SOUTH OF A CONCRETE POWER POLE (PU-23-7)

DH3040'AND 8.20M NORTH OF A TELEPHONE BOX.

DH3040'

DH3040'THE MARK IS A STANDARD 1993 GUAM GEODETIC NETWORK DISK

DH3040'STAMPED--2669--, SET IN A CONCRETE POST.

*** retrieval complete.

Elapsed Time $=00: 00: 03$

\section{Benchmark DK2736}

PROGRAM $=$ datasheet95, VERSION $=8.4$

1 National Geodetic Survey, Retrieval Date $=$ MAY 14, 2014

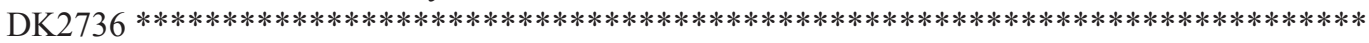

DK2736 DESIGNATION - NUTZ

DK2736 PID - DK2736

DK2736 STATE/COUNTY- GU/GUAM

DK2736 COUNTRY - US

DK2736 USGS QUAD - TALOFOFO (1975)

DK2736

DK2736 *CURRENT SURVEY CONTROL

DK2736

DK2736* NAD 83(MA11) POSITION- 1320 32.74295(N) 21513 43.41794(W) ADJUSTED

DK2736* NAD 83(MA11) ELLIP HT- 57.710 (meters) $\quad(06 / 27 / 12) \quad$ ADJUSTED

DK2736* NAD 83(MA11) EPOCH - 2010.00

DK2736* GUVD04 ORTHO HEIGHT - 4.28 (meters) 14.0 (feet) LEVELING

DK2736

DK2736 GEOID HEIGHT - 53.44 (meters)

DK2736 NAD 83(MA11) X - -5,070,340.329 (meters)

GEOID12A

COMP

DK2736 NAD 83(MA11) Y - 3,580,540.231 (meters)

DK2736 NAD 83(MA11) Z - 1,462,305.433 (meters)

COMP

COMP

DK2736 LAPLACE CORR - $\quad-4.41$ (seconds)

DEFLEC12A

DK2736 VERT ORDER - THIRD ?

DK2736

DK2736 FGDC Geospatial Positioning Accuracy Standards (95\% confidence, cm)

DK2736 Type Horiz Ellip Dist $(\mathrm{km})$

DK2736

DK2736 NETWORK

$1.28 \quad 1.45$

DK2736

DK2736 MEDIAN LOCAL ACCURACY AND DIST (004 points) $1.25 \quad 1.51 \quad 5.39$

DK2736

DK2736 NOTE: Click here for information on individual local accuracy

DK2736 values and other accuracy information.

DK2736

DK2736

DK2736.The horizontal coordinates were established by GPS observations

DK2736.and adjusted by the National Geodetic Survey in June 2012. 
DK2736

DK2736.NAD 83(MA11) refers to NAD 83 coordinates where the reference

DK2736.frame has been affixed to the stable Mariana tectonic plate.

DK2736

DK2736. The horizontal coordinates are valid at the epoch date displayed above

DK2736.which is a decimal equivalence of Year/Month/Day.

DK2736

DK2736. The orthometric height was determined by differential leveling.

DK2736. The vertical network tie was performed by a horz. field party for horz.

DK2736.obs reductions. Reset procedures were used to establish the elevation.

DK2736

DK2736.The X, Y, and Z were computed from the position and the ellipsoidal ht.

DK2736

DK2736.The Laplace correction was computed from DEFLEC12A derived deflections.

DK2736

DK2736.The ellipsoidal height was determined by GPS observations

DK2736.and is referenced to NAD 83.

DK2736

DK2736. The following values were computed from the NAD 83(MA11) position.

DK2736

DK2736; North East Units Scale Factor Converg.

DK2736;SPC GU - $\quad 182,567.325 \quad 102,304.569$ MT 1.00000007 +0 0017.7

DK2736;UTM $55 \quad-1,476,088.020 \quad 258,594.666$ MT $1.00032096 \quad-03052.5$

DK2736

DK2736! - Elev Factor $\mathrm{x}$ Scale Factor $=$ Combined Factor

DK2736!SPC GU $\quad-0.99999092 \times 1.00000007=0.99999099$

DK2736!UTM $55-0.99999092 \times 1.00032096=1.00031188$

DK2736

DK2736

DK2736|PID Reference Object Distance Geod. Az |

DK2736

DK2736| DK2735 BIRU

DK2736| DH2964 CLQT

dddmmss.s |

35.002 METERS 15701

DK2736

184.595 METERS 16031

DK2736

DK2736

DK2736

DK2736 NAD 83(1993)- 1320 32.74344(N) 21513 43.41842(W) AD(2004.00) 1

DK2736 ELLIP H (10/11/07) $57.708(\mathrm{~m}) \quad$ GP(2004.00) 42

DK2736

DK2736.Superseded values are not recommended for survey control.

DK2736

DK2736.NGS no longer adjusts projects to the NAD 27 or NGVD 29 datums.

DK2736.See file dsdata.txt to determine how the superseded data were derived.

DK2736

DK2736_U.S. NATIONAL GRID SPATIAL ADDRESS: 55PBQ5859476088(NAD 83)

DK2736

DK2736_MARKER: DD = SURVEY DISK

DK2736_SETTING: $0=$ UNSPECIFIED SETTING

DK2736 STAMPING: NUTZ 2007

DK2736_MARK LOGO: USACE

DK2736_MAGNETIC: $\mathrm{N}=$ NO MAGNETIC MATERIAL

DK2736_STABILITY: C = MAY HOLD, BUT OF TYPE COMMONLY SUBJECT TO

DK2736+STABILITY: SURFACE MOTION

DK2736_SATELLITE: THE SITE LOCATION WAS REPORTED AS SUITABLE FOR

DK2736+SATELLITE: SATELLITE OBSERVATIONS - July 20, 2007 
DK2736

DK2736 HISTORY - Date Condition Report By

DK2736 HISTORY - 20070720 MONUMENTED USACE

DK2736

DK2736

STATION DESCRIPTION

DK2736

DK2736'DESCRIBED BY US ARMY CORPS OF ENGINEERS 2007

DK2736'STATION LOCATION - THE STATION IS LOCATED ALONG THE OCEAN-SIDE OF

DK2736'ROUTE 4 IN THE MUNICIPALITY OF TALOFOFO, GUAM JUST NORTH OF TALOFOFO

DK2736'BAY AT ASQUIROGA BAY.

DK2736'

DK2736'OWNERSHIP - GUAM DEPARTMENT OF PUBLIC WORKS TO REACH THE STATION

DK2736'FROM THE INTERSECTION OF ROUTE 4 AND ROUTE 4A, TRAVEL NORTH ALONG

DK2736'ROUTE 4 FOR 0.5 MI (0.8 KM) TOWARDS ASQUIROGA BAY (AWAY FROM TALOFOFO

DK2736'BAY). THE BENCH MARK IS LOCATED ON THE OCEAN-SIDE OF ROUTE 4 AND ITS

DK2736'ASSOCIATED GUARDRAIL. THE BENCH MARK SITS FLUSH IN A CONCRETE SLURRY

DK2736'ADJACENT TO A U.S. ARMY CORPS OF ENGINEERS HURRICANE SHORE PROTECTION

DK2736'PROJECT. AN OLD PILLBOX SITS ON THE NORTH SIDE OF ASQUIROGA BAY, AND

DK2736'THE BAY IS A POPULAR SWIMMING/SNORKELING LOCATION.

DK2736'

DK2736'THE STATION IS AS FOLLOWS - 95 FT (29.0 M) AT AN ANGLE OF 340 FROM

DK2736'CONCRETE POWER POLE DC-YP 45-600 84-11. - 40 FT (12.2 M) 4 INCHES (10

DK2736'CM) AT AN ANGLE OF 263.5 FROM THE CENTERLINE OF ROUTE 4. - 50 FT (15.2

DK2736'M) AT AN ANGLE OF 150 FROM CONCRETE POWER POLE DC-YP 45-600 84-13. - 9

DK2736'FT (2.7 M) 6 INCHES (15 CM) AT AN ANGLE OF 263.5 FROM THE GUARDRAIL. -

DK2736'19 FT (5.8 M) 6 INCHES (15 CM) ALONG THE GUARDRAIL IF I START

DK2736'MEASURING FROM THE NORTH END OF IT.

DK2736'

DK2736'DESCRIBED BY JUSTIN PUMMELL, U.S. ARMY CORPS OF ENGINEERS, HONOLULU

DK2736'DISTRICT PHONE (808) 438-7038 E-MAIL JUSTIN.D.PUMMELL USACE.ARMY.MIL

*** retrieval complete.

Elapsed Time $=$ 00:00:04

\section{Benchmark DH3034}

PROGRAM $=$ datasheet95, VERSION $=8.3$

1 National Geodetic Survey, Retrieval Date $=$ FEBRUARY 22, 2014

DH3034 ********************************************************************************

DH3034 DESIGNATION - GGN 2555

DH3034 PID - DH3034

DH3034 STATE/COUNTY- GU/GUAM

DH3034 COUNTRY - US

DH3034 USGS QUAD - TALOFOFO (1975)

DH3034

DH3034 *CURRENT SURVEY CONTROL

DH3034

DH3034* NAD 83(1986) POSITION- $132010 . \quad$ (N) $2151416 . \quad$ (W) SCALED

DH3034* GUVD04 ORTHO HEIGHT - 2.648 (meters) 8.69 (feet) ADJUSTED

DH 3034

DH3034 GEOID HEIGHT - 53.48 (meters) GEOID12A

DH3034 VERT ORDER - FIRST CLASS II

DH3034

DH3034.The horizontal coordinates were scaled from a topographic map and have

DH3034.an estimated accuracy of $+/-6$ seconds. 
DH3034.

DH3034.The orthometric height was determined by differential leveling and

DH3034.adjusted by the NATIONAL GEODETIC SURVEY

DH3034.in May 2005.

DH3034

DH3034; North East Units Estimated Accuracy

DH3034;SPC GU - 181,870. 101,320. MT (+/- 180 meters Scaled)

DH3034

DH3034

SUPERSEDED SURVEY CONTROL

DH3034

DH3034.No superseded survey control is available for this station.

DH3034

DH3034 U.S. NATIONAL GRID SPATIAL ADDRESS: 55PBQ576753(NAD 83)

DH3034

DH3034 MARKER: DD = SURVEY DISK

DH3034 SETTING: 7 = SET IN TOP OF CONCRETE MONUMENT

DH3034_STAMPING: 2555

DH3034_MARK LOGO: GUAMLM

DH3034_MAGNETIC: N = NO MAGNETIC MATERIAL

DH3034_STABILITY: C = MAY HOLD, BUT OF TYPE COMMONLY SUBJECT TO

DH3034+STABILITY: SURFACE MOTION

DH3034 SATELLITE: THE SITE LOCATION WAS REPORTED AS SUITABLE FOR

DH3034+SATELLITE: SATELLITE OBSERVATIONS - May 04, 2004

DH3034

DH3034 HISTORY - Date Condition Report By

DH3034 HISTORY - 20040504 MONUMENTED GUAMLM

DH3034

DH3034

DH3034

STATION DESCRIPTION

DH3034'DESCRIBED BY GUAM DEPARTMENT OF LAND MANAGEMENT 2004 (TJT)

DH3034'GENERAL STATION LOCATION- THE STATION IS LOCATED IN THE MUNICIPALITY

DH3034'OF TALOFOFO.

DH3034'

DH3034'TO REACH NARRATIVE- TO REACH THE STATION FROM JUNCTION OF ROUTE 4 AND

DH3034'ROUTE 14, GO SOUTH ON ROUTE 4 FOR 0.5 MILES, TO THE STATION ON THE

DH3034'NORTHWEST CORNER PAULINO HEIGHTS ROAD AND SOUTHWEST OF TALOFOFO SURF

DH3034'BEACH PARK. THE STATION IS A CONCRETE MONUMENT FLUSH WITH SURFACE.

DH 3034

DH3034'MONUMENT DESCRIPTION AND MEASUREMENTS- THE STATION IS 6.60M SOUTHWEST

DH3034'OF CENTERLINE OF ROUTE 4, 18.60M NORTHWEST OF A CONCRETE POWER POLE

DH3034'AND 8.70M NORTHWEST OF CENTERLINE OF (AC) PAULINO HEIGHTS.

DH3034'

DH3034'THE MARK IS A STANDARD 1993 GUAM GEODETIC NETWORK DISK

DH3034'STAMPED--2555--, SET IN A CONCRETE POST.

*** retrieval complete.

Elapsed Time $=$ 00:00:08 

Prepared by the Sacramento Publishing Service Center.

For more information concerning this report, contact:

Director

U.S. Geological Survey

California Water Science Center

6000 J Street, Placer Hall

Sacramento, CA 95829

or visit our Web site at:

http://ca.water.usgs.gov 
